Review

\title{
Advances in understanding the role of cardiac glycosides in control of sodium transport in renal tubules
}

\author{
Syed Jalal Khundmiri ${ }^{1,2}$ \\ ${ }^{1}$ Division of Nephrology and Hypertension, Department of Medicine, and ${ }^{2}$ Department of Physiology \\ and Biophysics, University of Louisville, 570 S. Preston Street, Louisville, Kentucky 40202, USA
}
Correspondence should be addressed to S J Khundmiri Email syed.khundmiri@ louisville.edu

\begin{abstract}
Cardiotonic steroids have been used for the past 200 years in the treatment of congestive heart failure. As specific inhibitors of membrane-bound $\mathrm{Na}^{+} / \mathrm{K}^{+}$ATPase, they enhance cardiac contractility through increasing myocardial cell calcium concentration in response to the resulting increase in intracellular $\mathrm{Na}$ concentration. The half-minimal concentrations of cardiotonic steroids required to inhibit $\mathrm{Na}^{+} / \mathrm{K}^{+}$ATPase range from nanomolar to micromolar concentrations. In contrast, the circulating levels of cardiotonic steroids under physiological conditions are in the low picomolar concentration range in healthy subjects, increasing to high picomolar levels under pathophysiological conditions including chronic kidney disease and heart failure. Little is known about the physiological function of low picomolar concentrations of cardiotonic steroids. Recent studies have indicated that physiological concentrations of cardiotonic steroids acutely stimulate the activity of $\mathrm{Na}^{+} / \mathrm{K}^{+}$ ATPase and activate an intracellular signaling pathway that regulates a variety of intracellular functions including cell growth and hypertrophy. The effects of circulating cardiotonic steroids on renal salt handling and total body sodium homeostasis are unknown. This review will focus on the role of low picomolar concentrations of cardiotonic steroids in renal $\mathrm{Na}^{+} / \mathrm{K}^{+}$ATPase activity, cell signaling, and blood pressure regulation.
\end{abstract}

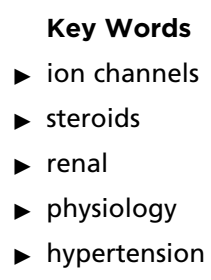

Journal of Endocrinology (2014) 222, R11-R24

\section{Introduction}

Physiological concentrations of cardiotonic steroids play a role in sodium homeostasis. However, the mechanisms are unknown and a subject of current investigation in several laboratories. Cardiotonic steroids were discovered as specific inhibitors of the sodium pump, $\mathrm{Na}^{+} / \mathrm{K}^{+}$ATPase. However, the circulating levels, at in picomolar concentrations, are insufficient to inhibit $\mathrm{Na}^{+} / \mathrm{K}^{+}$ATPase. Endogenous cardiotonic steroids have been implicated in several forms of hypertension (Blaustein et al. 2009, Hamlyn \& Manunta 2011), including hypertension associated with chronic kidney disease. The hypertensive effects of cardiotonic steroids on blood pressure have been attributed to their effects on vasculature and CNS centers that control sodium homeostasis and have been the subject of several recent excellent review articles (Tian \& Xie 2008, Lingrel 2010, Blaustein et al. 2012). In vascular and cardiac cells, binding of cardiotonic steroids leads to a decrease in $\mathrm{Na}^{+} / \mathrm{K}^{+}$ATPase activity and an increase in cytosolic $\mathrm{Na}^{+}$concentration $\left(\left[\mathrm{Na}^{+}\right]\right.$cyt). The increase in $\left[\mathrm{Na}^{+}\right]$cyt results in reverse mode action of the $\mathrm{Na}^{+} / \mathrm{Ca}^{2+}$

Published by Bioscientifica Ltd 
exchanger, which would cause an increase in cytosolic calcium that will in turn cause increased contraction and an increase in blood pressure (Askari et al. 1988, Blaustein et al. 2006). The positive ionotropic effects of digitalis and its derivatives on cardiac sarcolemma were described by Klaus \& Lee (1969) and Lee \& Klaus (1971). Akera and colleagues demonstrated that enhanced intracellular sodium transients caused by the positive ionotropic effects of digitalis and its derivatives would increase intracellular calcium, and hence, increase myocardial contractility (Akera 1977, Akera \& Brody 1977, Brody \& Akera 1977, Choi \& Akera 1977, Weaver et al. 1977, Akera \& Ng 1991). Studies from Askari's laboratory experimentally showed ionotropic effects of cardiotonic steroids on cardiac myocytes. They demonstrated that treatment of cardiac myocytes increases intracellular calcium and activates a signaling cascade that involves production of ROS and activation of the EGFR-Src kinase pathway leading to cardiac hypertrophy (Xie \& Askari 2002, Mohammadi et al. 2003). This simplistic view was later on modified by the Blaustein hypothesis of the 'Plasmerosome'. He argued that in vascular smooth muscle, sarcoplasmic reticulum (SR) components called 'junctional SR' are close to the plasma membrane (PM) and this association forms a 'restricted cytoplasmic space' between the PM and SR. He called this complex of junctional SR, the adjacent PM, and the restricted cytoplasmic space the plasmerosome, which that contains the highly sensitive $\mathrm{Na}^{+} / \mathrm{K}^{+}$ATPase $\alpha 3$ or $\alpha 2$ and the $\mathrm{Na}^{+} / \mathrm{Ca}^{2+}$ exchanger. The plasmerosome has very high $\mathrm{Na}^{+} / \mathrm{K}^{+}$and $\mathrm{Ca}^{2+}$ concentrations. The hypothesis suggests that very low levels of circulating endogenous cardiotonic steroids modify the ionic balance in the plasmerosome, causing changes in contraction and development of blood pressure (Blaustein et al. 1998). However, this hypothesis has been proven only in rodents, which express a less sensitive $\mathrm{Na}^{+} / \mathrm{K}^{+}$ATPase $\alpha 1$-subunit unlike humans and other species that express a highly ouabain-sensitive $\alpha 1$. Therefore, it remains to be determined whether different $\mathrm{Na}^{+} / \mathrm{K}^{+}$ATPase isoforms play such different roles in cardiotonic steroid-mediated blood pressure development in humans. This review highlights recent exciting studies investigating the effects of physiological and pathophysiological concentrations of cardiotonic steroids on renal salt reabsorption (Aizman et al. 2001, Abramowitz et al. 2003, Aizman \& Aperia 2003, Contreras et al. 2006, Khundmiri et al. 2006, 2007, 2014, Aperia 2007, Nguyen et al. 2007, 2011, Holthouser et al. 2010, Jansson et al. 2012, Bignami et al. 2013, Blanco \& Wallace 2013).

\section{Cardiotonic steroids: structure, synthesis, and hypertension}

Cardiotonic steroids are a family of compounds that are referred to variously as cardiac glycosides, ouabain, digoxin, digitalis, bufadienolides, endogenous ouabain (EO), ouabain-like factor (OLF), and digoxin-like factor (DLF or DLIF) to name a few. For the remainder of the review, the term cardiotonic steroids will be used, unless referring to a specific member of the cardiotonic steroid family. The structural features important for the action of cardiotonic steroids are a cyclopentaphenanthrene nucleus with $\mathrm{AB}$ cis, $\mathrm{BC}$ trans, and $\mathrm{CD}$ cis, a $\mathrm{C}-14$ hydroxyl group, and an unsaturated lactone ring in the $\beta$ configuration. The lactone rings are hydroxylated at positions $1,5,11,14$, and 19 for ouabain while digoxin is hydroxylated at position 14 of the lactone ring. In many plant-derived cardiotonic steroids, a sugar group is present at C3 (Fig. 1). Ouabain has a rhamnose sugar group while digoxin and digitoxin contain digitoxose. The sugar moiety does not appear to play a role in the effects of cardiotonic steroids on salt homeostasis (Goto et al. 1992, Blaustein \& Hamlyn 2010). For example, similar to ouabain, ouabagenin binds with the same affinity to $\mathrm{Na}^{+} / \mathrm{K}^{+}$ATPase (Yoda \& Yoda 1981). Data from our laboratory indicate that treatment with picomolar concentrations of ouabagenin for $24 \mathrm{~h}$ increases $\mathrm{Na}^{+} / \mathrm{K}^{+}$ATPase activity in human kidney proximal tubule cells similar to picomolar concentrations of ouabain (Fig. 2). Based on their origin, cardiotonic steroids are divided into plantderived cardenolides (e.g., ouabain, digoxin, and digitalis) and animal-originated bufadienolides (e.g., marinobufagenin and telocinobufagin) (Bagrov \& Shapiro 2008). Plant-derived cardiotonic steroids contain a five-membered lactone ring while the cardiotonic steroids of animal origin contain a six-membered lactone ring (Schoner \& Scheiner-Bobis 2005). In humans, one cardiotonic steroid isolated from adrenal glands and plasma appears to be identical to plant-derived ouabain by NMR and mass spectroscopy (Nicholls et al. 2009) and is designated as EO.

Several investigators have demonstrated that cardiotonic steroids are synthesized and/or stored in the adrenal glands (Boulanger et al. 1993). Interestingly, both orally and parenterally administered cardiotonic steroids are taken up by the adrenal glands. The intestines only absorb $3-5 \%$ of orally administered cardiotonic steroids (Greeff \& Fox 1984, Boulanger et al. 1993, Kitano et al. 1998). The mechanism of regulation of this process is unknown, as is the contribution of absorbed cardiotonic steroids to circulating plasma levels. Consistent with the hypothesis

Published by Bioscientifica Ltd 

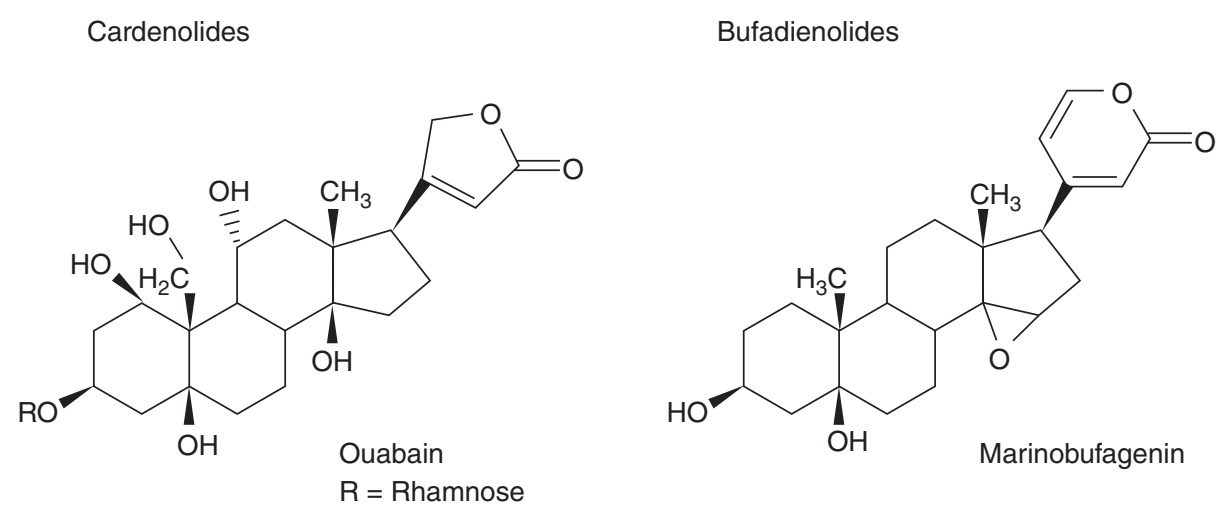

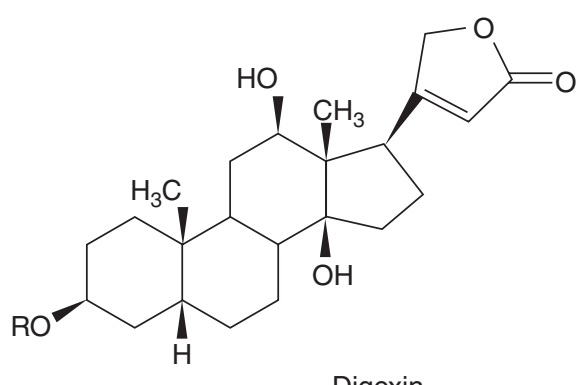

Digoxin

$\mathrm{R}=3$ Digitoxoses<smiles>C[C@]12CC[C@@H](O)C[C@]1(O)CCC1C2CC[C@]2(C)C(c3ccoc(=O)c3)CC[C@@]12O</smiles><smiles>C[C@]12CCC3C4CC[C@H](O)CC4CCC3[C@@]1(O)CC[C@@H]2c1ccoc(=O)c1</smiles>

19-Norbufalin

Figure 1

Structure of the common cardiotonic steroids.

that cardiotonic steroids are synthesized in the adrenal glands, adrenalectomy has been demonstrated to decrease circulating levels of cardiotonic steroids (Masugi et al. 1988, Hamlyn et al. 1991). In patients with adrenal tumors, the presence of high blood pressure appears to correlate with elevated circulating levels of cardiotonic steroids, as both blood pressure and circulating cardiotonic steroid concentrations were normalized after removal of the adenomas (Doris et al. 1989, Komiyama et al. 1999, Schoner \& Scheiner-Bobis 2005). Synthesis of cardiotonic steroids in the adrenal glands, hypothalamus, and cells cultured from bovine adrenal glands and rat pheochromocytoma has been demonstrated (Hamlyn et al. 1991, Mathews et al.
1991, Schneider et al. 1998a,b, Kawamura et al. 1999, Komiyama et al. 2001). The synthesis of endogenous cardiotonic steroids is upregulated by ACTH, alpha adrenergic and dopaminergic stimulation, angiotensin II through stimulation of AT2 receptor, hypoxia, and physical exercise (el-Masri et al. 2002, Schoner 2002, Qazzaz et al. 2004, Dmitrieva et al. 2005, Schoner \& Scheiner-Bobis 2005, 2007a, b, 2008, Loreaux et al. 2008, Lorenz et al. 2008, Manunta et al. 2010).

The role of nanomolar concentrations of cardiotonic steroids in the development of hypertension, regulation of blood pressure, salt homeostasis, and risk of cardiovascular disease (CVD) has been extensively studied and reviewed 
A

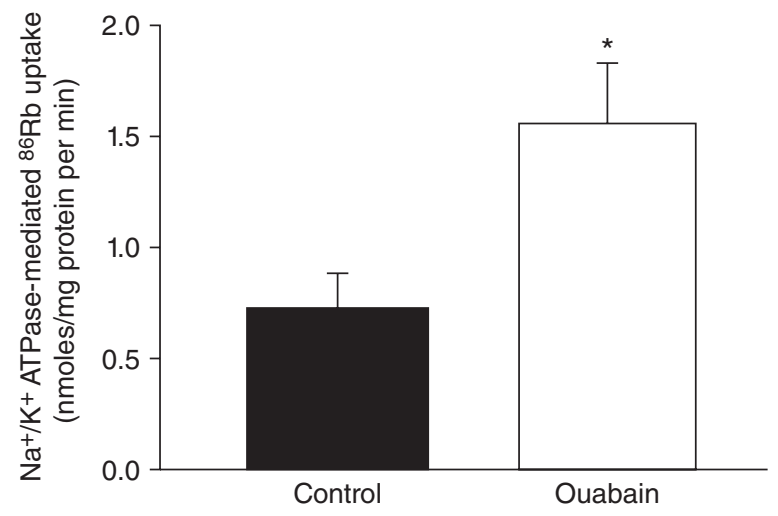

B

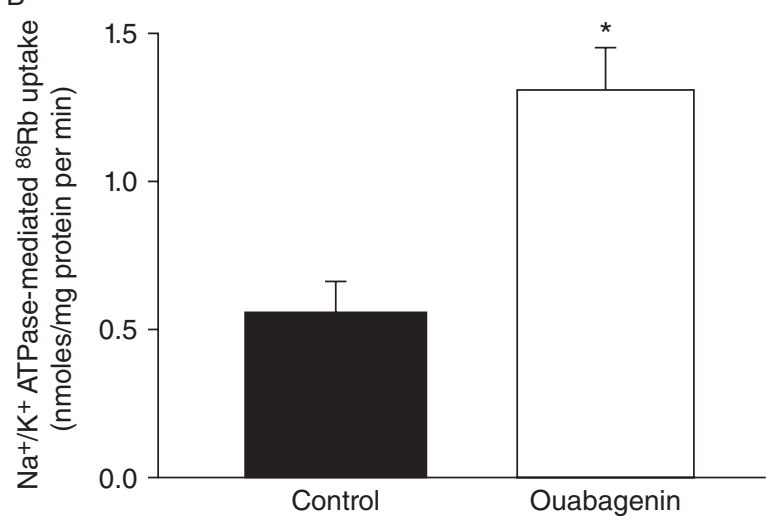

Figure 2

Effect of ouabagenin on $\mathrm{Na}^{+} / \mathrm{K}^{+}$ATPase activity in human kidney proximal tubule cells. Human kidney cells (HKC11) were treated with $10 \mathrm{pM}$ ouabagenin or $10 \mathrm{pM}$ ouabain for $24 \mathrm{~h}$. $\mathrm{Na}^{+} / \mathrm{K}^{+}$ATPase-mediated ${ }^{86} \mathrm{Rb}$ uptake was measured as ouabain-sensitive rubidium uptake. The results demonstrate that both ouabagenin and ouabain increase $\mathrm{Na}^{+} / \mathrm{K}^{+}$ATPase activity in HKC11 cells. Each bar indicates values as mean \pm s.E.M. from six individual experiments $(n=6) .{ }^{*} P<0.05$ by the Student's $t$-test.

(Schoner \& Scheiner-Bobis 2007a,b, Fedorova et al. 2010a,b, Lingrel 2010, Liu \& Xie 2010). The average circulating level of cardiotonic steroids in normotensive controls is $253 \mathrm{pmol} / \mathrm{l}(30-600 \mathrm{pmol} / \mathrm{l})$. The concentrations of cardiotonic steroids have been shown to increase to approximately 930 pmol/1 (300-1700 pmol/l) in patients with hypertension, CVDs, cardiorenal syndrome, and chronic kidney disease (Mohmand et al. 2005, Kennedy et al. 2006, Stella et al. 2008), which is higher than in healthy subjects but still significantly lower than the levels achieved with pharmacological doses of digoxin and also lower than the levels required to inhibit $\mathrm{Na}^{+} / \mathrm{K}^{+}$ ATPase significantly. The correlation between levels of cardiotonic steroids and CVD indicates a potential pathophysiological role of cardiotonic steroids in the development of these disorders.

\section{$\mathrm{Na}^{+} / \mathrm{K}^{+}$ATPase structure and function}

All cells maintain a cytoplasmic environment that is low in sodium and high in potassium. Studies in the early 1950s using red blood cells solved the mystery of how this ionic gradient is maintained (Glynn 1956). In 1957, Skou discovered $\mathrm{Na}^{+} / \mathrm{K}^{+}$ATPase to be the enzyme responsible for the maintenance of these ion gradients for which he was honored with the Nobel Prize in 1997 (Skou 1957). $\mathrm{Na}^{+} / \mathrm{K}^{+}$ATPase uses the energy from hydrolysis of ATP to transport three $\mathrm{Na}^{+}$out of the cell and two $\mathrm{K}^{+}$into the cell (Skou \& Esmann 1992). Since its discovery, a tremendous scientific effort has been devoted to the understanding of the structure and function of this enzyme due to its physiological importance. The ionic gradients created by $\mathrm{Na}^{+} / \mathrm{K}^{+}$ATPase create a membrane potential in the excitable cells of the nervous system and muscles. $\mathrm{Na}^{+} / \mathrm{K}^{+}$ATPase also acts as an energy transducer by converting the chemical energy of ATP to create ionic concentration gradients. This gradient is utilized by cells to energize the transport of various ions and solutes such as glucose, amino acids, and neurotransmitters across the membrane against their chemical gradients, for absorption of nutrients from intestines and to regulate cell volume (Martin 2005). This gradient also plays an important role in the reabsorption of sodium and various vital solutes in kidney (Jorgensen \& Skou 1969).

$\mathrm{Na}^{+} / \mathrm{K}^{+}$ATPase is a heterotrimeric enzyme and it consists of an $\alpha$-subunit, a $\beta$-subunit, and a FXYD (or $\gamma$-subunit) (Sweadner 1989, Lingrel \& Kuntzweiler 1994, Malik et al. 1996, Kaplan 2002). The $\alpha$-subunit, a $110 \mathrm{kDa}$ protein, is the catalytic subunit that has binding sites for $\mathrm{Na}^{+}$and $\mathrm{K}^{+}$and ten transmembrane helices, three cytoplasmic domains, an actuator domain (A), the nucleotide-binding domain $(\mathrm{N})$, and the phosphorylation domain (P). The catalytic subunit has recently been shown to have a canonical caveolin-binding domain (CBD) that regulates the association of the $\alpha$-subunit with caveolin 1 (Cai et al. 2008). The $\beta$-subunit, a $36 \mathrm{kDa}$ protein, has a small N-terminal cytoplasmic domain, one transmembrane helix, and a large highly glycosylated extracellular domain, and it is required for maturation and insertion of the $\mathrm{Na}^{+} / \mathrm{K}^{+}$ATPase complex into the membrane (McDonough et al. 1990, Geering 1991, Lutsenko \& Kaplan 1993, Beguin et al. 1998a,b, Hasler et al. 1998, Blanco 2005). The $\beta$-subunit also forms bridges between adjacent cells, which are critical for maintaining the integrity of tight junctions and apical and basolateral polarity in epithelial cells as well as preventing the translocation of proteins from apical to basolateral

Published by Bioscientifica Ltd 
membranes and vice versa (Rajasekaran \& Rajasekaran 2003, 2009, Barwe et al. 2005, Tokhtaeva et al. 2009, 2011). Members of the FXYD protein family are tissue-specific and regulate the activity of the pump (Sweadner et al. 2003, Geering 2008). To date, four isoforms of the $\alpha$ subunit ( $\alpha 1-4)$, three isoforms of the $\beta$-subunit ( $\beta 1-3)$, and at least seven isoforms of FXYD have been identified (Forbush et al. 1978, Sweadner \& Rael 2000, Blanco 2005) adding to the diversity of $\mathrm{Na}^{+} / \mathrm{K}^{+}$ATPase function. The a1-subunit is ubiquitously expressed and is the only subunit expressed in the kidneys, while the other isoforms are tissue-specific. The $\alpha 2$-subunit is expressed in skeletal muscle, smooth muscle, heart, brain, lung, and adipocytes (Donnet \& Sweadner 2003, Blanco 2005, Bystriansky \& Kaplan 2007, Lingrel 2010). The $\alpha 3$-subunit is expressed in neurons, ovaries, and adult human heart (Sweadner 1989, Kaplan 2002, Lingrel 2010), while the $\alpha 4$-subunit is expressed in sperm (Shamraj \& Lingrel 1994, Woo et al. 1999, 2000, Wagoner et al. 2005, Sanchez et al. 2006, Jimenez et al. 2010, 2011a,b, 2012). The $\mathrm{Na}^{+} / \mathrm{K}^{+}$ATPase $\alpha 1$-subunit in rodents is the least sensitive to cardiotonic steroids, whereas the $\alpha 2-, \alpha 3-$, and $\alpha 4$-subunits are highly sensitive to cardiotonic steroids. However, all $\alpha$-subunits have a similar sensitivity to cardiotonic steroids in humans, pigs, and other species. Recent studies using high-resolution structure analysis provide in-depth understanding of the ion-transporting function and allosteric modulations of $\mathrm{Na}^{+} / \mathrm{K}^{+}$ATPase in the $\mathrm{Na}^{+}$and $\mathrm{K}^{+}$ transporting states (Morth et al. 2007, 2009, 2011, Pedersen et al. 2007, Schack et al. 2008, Ogawa et al. 2009, Shinoda et al. 2009, Toustrup-Jensen et al. 2009, Kanai et al. 2013, Laursen et al. 2013).

$\mathrm{Na}^{+} / \mathrm{K}^{+}$ATPase is the main target of cardiotonic steroids such as ouabain and digoxin. Extensive research has primarily been directed at the ion-transporting properties of therapeutic doses of cardiotonic steroids, and the resulting ionotropic effect due to inhibition of $\mathrm{Na}^{+} / \mathrm{K}^{+}$ATPase and also the resulting increase in intracellular calcium concentrations in vasculature and heart muscle. In addition to its transporting function, $\mathrm{Na}^{+} / \mathrm{K}^{+}$ATPase plays an important role in cell signaling (Xie \& Askari 2002). The elegant work from the laboratories of Xie and Askari has elucidated this important role of $\mathrm{Na}^{+} / \mathrm{K}^{+}$ATPase that is probably involved in diverse cellular functions and pathophysiological states such as cell growth, hypertrophy, ischemia, development and postnatal maturation of kidneys, and as yet undefined processes (Kometiani et al. 1998, 2005, Xie et al. 1999, Liu et al. 2000, 2007a,b, Aizman et al. 2001, Mohammadi et al. 2001, Aizman \& Aperia 2003, Andersson et al. 2004, Li et al. 2006, 2009, 2010, Liang et al. 2006, Tian et al. 2006, 2010, Aperia 2007, 2012, Nguyen et al. 2007, Kennedy et al. 2008, Tian \& Xie 2008, Khodus et al. 2011, Brashear et al. 2012, Blanco \& Wallace 2013, Burlaka et al. 2013, Fontana et al. 2013, Wu et al. 2013). The laboratory of Zijian Xie made an important discovery by demonstrating that a population of non-ion-transporting and highaffinity $\mathrm{Na}^{+} / \mathrm{K}^{+}$ATPase resides in caveolae, forming a signaling complex with Src kinase (Pierre \& Xie 2006). When cardiotonic steroids at low picomolar to nanomolar concentrations bind to $\mathrm{Na}^{+} / \mathrm{K}^{+}$ATPase in the caveolae, this activates Src, which in turn results in transactivation of EGFR and activation of the PI3K-Akt pathway, the Ras-Raf-ERK MAP kinase pathway, IP3R activation, and calcium oscillations, resulting in regulation of earlyresponse genes associated with cell growth, motility, and metabolic pathways (Peng et al. 1996, Kometiani et al. 1998, Contreras et al. 1999, 2004, 2006, Aizman et al. 2001, Abramowitz et al. 2003, Dmitrieva \& Doris 2003, Dong et al. 2004, Khundmiri et al. 2006, 2007, Liu \& Askari 2006, Liu et al. 2007a,b, 2011, Pierre et al. 2008, Quintas et al. 2010, Morrill et al. 2012, Bai et al. 2013, Wu et al. 2013, Rincon-Heredia et al. 2014).

\section{Endogenous cardiotonic steroids in cardiac and renal diseases}

As early as the 1960s, it became evident that activation of the renin-angiotensin-aldosterone system alone cannot explain the physiological and pathophysiological responses to acute or chronic blood volume regulation in salt-sensitive hypertension (Schrier \& De Wardener 1971a,b, Schrier \& Berl 1975). de Wardener et al. (1961) demonstrated that saline infusion-induced natriuresis is maintained even under normal renal perfusion pressure and glomerular filtration rate. This observation led to the postulation of 'the third factor' theory, which suggests that volume expansion is associated with an increase in a circulating factor that inhibits $\mathrm{Na}^{+} / \mathrm{K}^{+}$ATPase activity (de Wardener et al. 1961, de Wardener \& MacGregor 2002, de Wardener 2003, de Wardener et al. 2004). Bricker and colleagues, based on their studies in uremic human subjects and experimental rat models of chronic kidney disease, postulated that the circulating $\mathrm{Na}^{+} / \mathrm{K}^{+}$ATPase inhibitory factor is involved in the progression of renal failure and pathogenesis of uremic syndrome (Bricker et al. 1968, 1970, 1972, 1993, Slatopolsky et al. 1968, 1970, Bricker \& Klahr 1970, Bourgoignie et al. 1971, Bricker 1972). The identification and characterization of the circulating $\mathrm{Na}^{+} / \mathrm{K}^{+}$ATPase antagonist remained elusive

Published by Bioscientifica Ltd 
for a long time. After painstaking research spanning three decades, two groups independently identified the circulating factor(s) as substances similar to plant-derived ouabain and digoxin that are synthesized in the mammalian adrenal glands (Hamlyn et al. 1982, 1987, 1989, 1991, 1996, 1998, Craver \& Valdes 1983, Graves et al. 1983, 1984, Valdes 1985a,b,c, Valdes et al. 1985, 1988, Skogen et al. 1987, Lackner et al. 1988, Siegfried \& Valdes 1988, Shaikh et al. 1991, Qazzaz \& Valdes 1996, Qazzaz et al. 1996a,b, 2000, Ferrandi et al. 1997, Jortani \& Valdes 1997, Perrin et al. 1997, Grider et al. 1999, Manunta et al. 2001a,b, Pierdomenico et al. 2001, el-Masri et al. 2002, El-Mallakh et al. 2007). Bagrov and colleagues identified the presence of endogenous bufadienolides, marinobufagenin, and telocinobufagin, in plasma of rats with renal failure, diabetes, and preeclampsia, and in plasma from patients with congestive heart failure and renal failure (Bagrov et al. 1996, 2005, 2009, Fedorova et al. 1998, 2005a,b, 2010a,b, 2012, Gonick et al. 1998, Lopatin et al. 1999, Averina et al. 2006, Kennedy et al. 2006, Zvartau et al. 2006, Anderson et al. 2008, Bagrov \& Shapiro 2008, Tian et al. 2010, Kolmakova et al. 2011). Recent studies have indicated that endogenous cardiotonic steroids also play a significant role in the pathogenesis of polycystic kidney disease (Nguyen et al. 2007, 2011, Blanco \& Wallace 2013, Jansson et al. 2013).

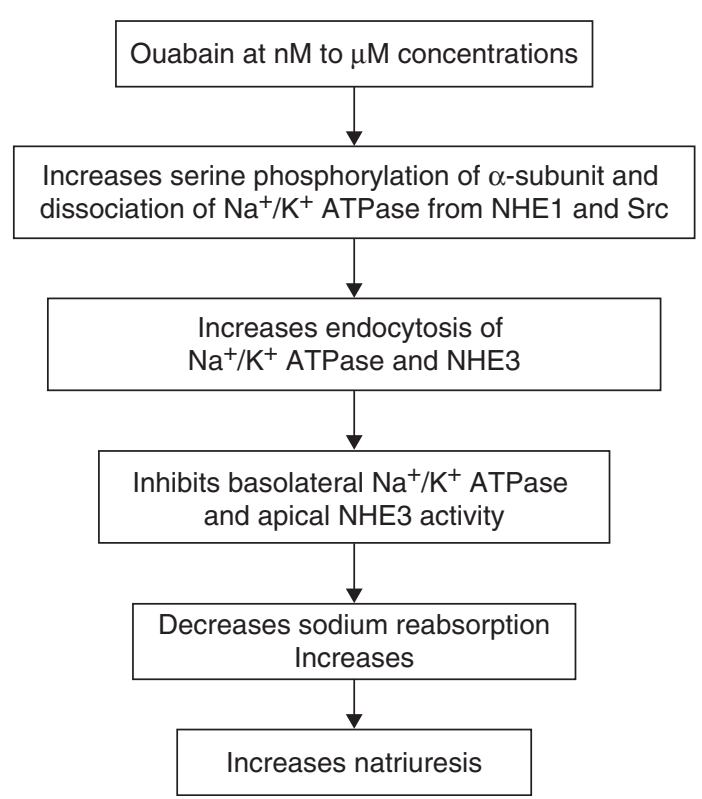

\section{Effects of low nanomolar to picomolar concentrations of ouabain on $\mathrm{Na}^{+} / \mathrm{K}^{+}$ ATPase activity}

A significant advance in the understanding of the role of $\mathrm{Na}^{+} / \mathrm{K}^{+}$ATPase and cardiotonic steroids in human physiology has been the recognition of the dosedependent effects of cardiotonic steroids on $\mathrm{Na}^{+} / \mathrm{K}^{+}$ ATPase activities. In a recent study, Manunta et al. (2006) have demonstrated that, in normotensive control subjects, plasma levels of cardiotonic steroids were $0.43 \pm$ $0.08 \mathrm{nmol} / \mathrm{l}$ and urinary cardiotonic steroid excretion was $1.04 \pm 0.13 \mathrm{nmol} /$ day. In patients with high salt loading for 3 days, the plasma levels of endogenous cardiotonic steroids increased to $5.8 \pm 2.2 \mathrm{nmol} / \mathrm{l}$, and the urinary cardiotonic steroid excretion increased to $1.69 \pm 0.27 \mathrm{nmol} /$ day. Similar concentrations were reported by Stella et al. (2008) in end-stage renal disease (ESRD) patients. They demonstrated that increased endogenous cardiotonic steroid levels are independently associated with left ventricular hypertrophy (LVH) and eccentric non-dilated hypertrophy (EH) in ESRD patients. They concluded that LVH and EH in this patient cohort were associated with increased cardiac glycoside levels stimulated by chronic volume overload. One possible explanation is that sodium retention due to renal failure would increase volume load, and increase synthesis and/or

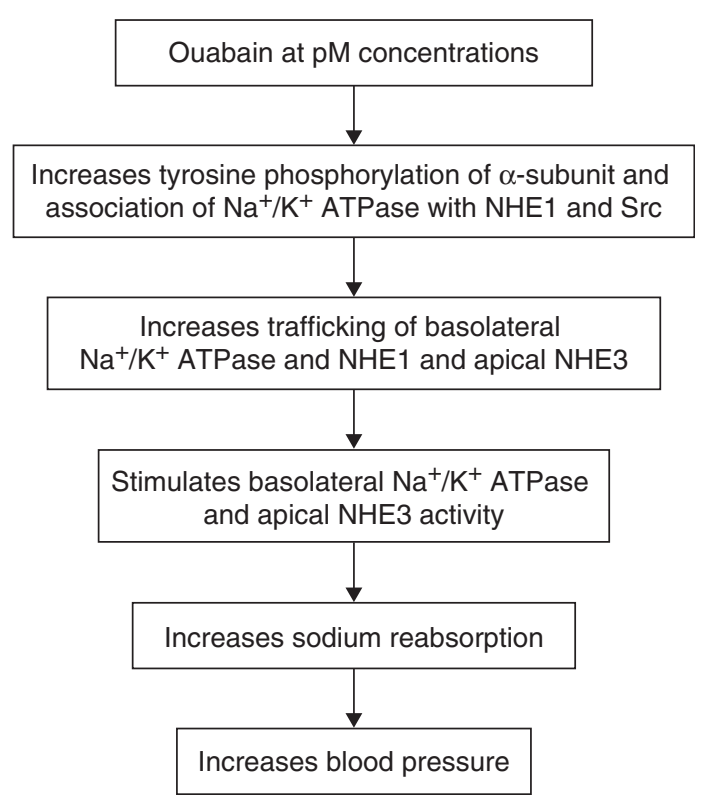

Figure 3

A comparison of the effects of high and low concentrations of ouabain on renal proximal tubular sodium reabsorption.

http://joe.endocrinology-journals.org DOI: 10.1530/JOE-13-0613 (c) 2014 Society for Endocrinology Printed in Great Britain
Published by Bioscientifica Ltd 
decrease clearance of cardiotonic steroids. The increased circulating levels of endogenous cardiotonic steroids would result in increased cardiac contractility and peripheral vascular resistance (Schoner \& Scheiner-Bobis $2007 a, b)$. Ferrari et al. (2006) proposed a dual mechanism for the hypertensogenic action of endogenous cardiotonic steroids, where they suggest that at, low concentrations, cardiotonic steroids inhibit the $\mathrm{Na}^{+} / \mathrm{K}^{+}$ATPase $\alpha 2$ subunit in vessels and increase the activity of renal $\mathrm{Na}^{+} / \mathrm{K}^{+}$ATPase $\alpha 1$-subunits, resulting in an increase in the intracellular calcium concentration in the vascular cells and volume expansion due to increased sodium reabsorption in the kidney. Both these factors together would contribute to the increase in blood pressure. In fact, Brown et al. (1962) described stimulation of the sodium pump by cardiotonic steroids at concentrations that cause positive ionotropic effects. Subsequently, Lee \& Klaus (1971) and Cohen et al. (1976) described similar effects of digitalis and its derivatives on the sodium pump. We (Khundmiri et al. 2006, 2007) and others (Bluschke et al. 1976, Gao et al. 2002, Ferrari 2010) have demonstrated that low concentrations of cardiotonic steroids increase $\mathrm{Na}^{+} / \mathrm{K}^{+}$ATPase-mediated ion transport in renal proximal tubule cells. As early as 1914, Douglas Cow discovered microcirculation between kidneys and adrenal glands (Cow 1914), which would indicate that EO synthesized in the adrenal glands could directly affect the sodium reabsorption in the kidneys without reaching the systemic circulation. The increased sodium reabsorption would lead to an increase in the volume followed by vascular changes to increase blood pressure. Recent studies from our laboratory have demonstrated that treatment with low-dose ouabain, concentrations similar to those present in ESRD patients, increases blood pressure in rats and increases $\mathrm{Na}^{+} / \mathrm{K}^{+}$ATPase activity in basolateral membranes prepared from kidney cortex. The increase in activity was dependent upon the presence of NHE1 (SLC9A1) expression and was inhibited by specific inhibitors of NHE1 (Holthouser et al. 2010). We also demonstrated that low-dose cardiotonic steroids increase the association between $\mathrm{Na}^{+} / \mathrm{K}^{+}$ATPase and NHE1 and that this association is critical for activation of the SrcEGFR signaling cascade. Mutation analysis of the $\mathrm{Na}^{+} / \mathrm{K}^{+}$ ATPase and NHE1 demonstrated that the N-terminal CBD of the $\mathrm{Na}^{+} / \mathrm{K}^{+}$ATPase $\alpha$-subunit and the scaffolding domain of NHE1 are the critical components for this association. Interestingly, total internal reflection fluorescence microscopy (TIRFM) showed that deletion of the $\mathrm{N}$-terminal CBD of $\mathrm{Na}^{+} / \mathrm{K}^{+}$ATPase resulted in the failure of trafficking of $\mathrm{Na}^{+} / \mathrm{K}^{+}$ATPase $\alpha$-subunit and NHE1 to the basolateral membranes. Mutations in the scaffold domain or the activity domain of NHE1 prevented the induction of the increase in $\mathrm{Na}^{+} / \mathrm{K}^{+}$ATPase activity by ouabain (Khundmiri et al. 2014). These data indicate that an association between $\mathrm{Na}^{+} / \mathrm{K}^{+}$ATPase and NHE1 triggered by low-dose ouabain is essential for Src activation and the increase in sodium reabsorption in the proximal tubular cells (Fig. 3). Traditionally, the $\beta$-subunit of $\mathrm{Na}^{+} / \mathrm{K}^{+}$ATPase has been demonstrated to facilitate the trafficking of the $\alpha \beta$ heteroenzyme to the PM. Our recent observation that mutations affecting the CBD prevented the membrane trafficking of the $\mathrm{Na}^{+} / \mathrm{K}^{+}$ATPase in the presence of endogenous $\beta$-subunit indicates an exciting possibility that the CBD may also play a role in the association of the $\alpha$ - and $\beta$-subunit. Further experiments are required to confirm this possibility.

A major observation in all studies where $\mathrm{Na}^{+} / \mathrm{K}^{+}$ ATPase activity was shown to be stimulated by low concentrations of cardiotonic steroids was that the effect was acute. The mechanisms of the chronic effects of cardiotonic steroids at low concentrations are not known. Recent work at our laboratory has indicated that the increase in $\mathrm{Na}^{+} / \mathrm{K}^{+}$ATPase activity was accompanied by an increase in secretion of angiotensin II in human proximal tubule cells (Khundmiri SJ, unpublished observations). These results indicate that the chronic

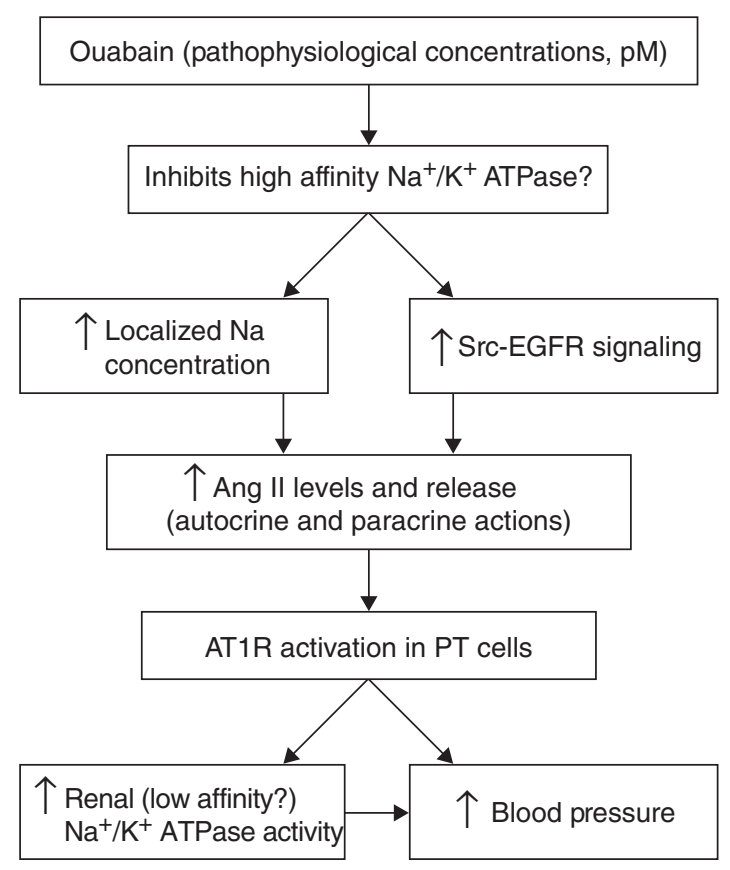

Figure 4

A hypothetical model for the effects of pathophysiological (pM) concentrations of ouabain (endogenous cardiotonic steroids) on blood pressure.

Published by Bioscientifica Ltd. 
effects of cardiotonic steroids may be mediated through angiotensin II. Based on our preliminary unpublished data, we propose a hypothesis that pathophysiological concentrations of endogenous cardiotonic steroids such as ouabain would inhibit high-affinity $\mathrm{Na}^{+} / \mathrm{K}^{+}$ATPase residing in caveoli, resulting in a localized increase in $\mathrm{Na}^{+}$concentration near the caveolar membranes. The increase in localized $\left[\mathrm{Na}^{+}\right] \mathrm{i}$ and Src and EGFR activation promotes synthesis and release of angiotensin II from the proximal tubule cells. The released angiotensin II acts in both autocrine and paracrine manners to activate proximal tubular AT1R. Activation of AT1R will then increase sodium reabsorption by increasing the activities of NHE3 and $\mathrm{Na}^{+} / \mathrm{K}^{+}$ATPase resulting in an increase in blood pressure (Fig. 4). In turn, angiotensin II may have effects on cardiotonic steroid release, activity, or intracellular signaling. Thus, these studies indicate a connection between the renin-angiotensin-aldosterone system, $\mathrm{ACTH}$, and cardiotonic steroids that would result in a sustained increase in blood pressure in patients with chronic kidney disease and cardiorenal syndrome. Another possible mechanism would be a decrease in secretion of hormones that inhibit $\mathrm{Na}^{+} / \mathrm{K}^{+}$ATPase activity (PTH) or loss of their effects on inhibition of sodium transport in the kidney (dopamine) due to pathophysiological concentrations of cardiotonic steroids (Brown et al. 1983, 1987, Zhang \& Yuan 2010, Zhang et al. 2010, Apel et al. 2013). Further studies will unravel these pathways.

\section{Conclusions}

Understanding of the role of cardiotonic steroids in the pathophysiology of cardiac and renal disorders has progressed exponentially in the last two decades. The discovery of the role of $\mathrm{Na}^{+} / \mathrm{K}^{+}$ATPase in signal transduction, a function distinct from its ion transport properties, demonstrates that $\mathrm{Na}^{+} / \mathrm{K}^{+}$ATPase is a multifaceted protein involved in the regulation of several physiological processes over and above its classical role in the maintenance of the intracellular ionic milieu. Understanding the roles of low physiological and pathophysiological concentrations of cardiotonic steroids in the regulation of $\mathrm{Na}^{+} / \mathrm{K}^{+}$ATPase, intracellular signaling, and hormonal signaling is essential to delineating the functions of these substances in the regulation of sodium homeostasis in normal and pathophysiological states. These studies will open up development of new therapies for the control of blood pressure and renal disorders linked with aberrant salt homeostasis.

\section{Declaration of interest}

The author declares that there is no conflict of interest that could be perceived as prejudicing the impartiality of the review.

\section{Funding}

This work was supported by grants from the American Heart Association in the form of Scientist Development Grant and Grant-in-Aid.

\section{Acknowledgements}

The author acknowledges Dr Eleanor Lederer and Rebecca Murray for critical reading of the manuscript. The author also acknowledges Dr Lederer's continued support.

\section{References}

Abramowitz J, Dai C, Hirschi KK, Dmitrieva RI, Doris PA, Liu L \& Allen JC 2003 Ouabain- and marinobufagenin-induced proliferation of human umbilical vein smooth muscle cells and a rat vascular smooth muscle cell line, A7r5. Circulation 108 3048-3053. (doi:10.1161/01.CIR. $0000101919.00548 .86)$

Aizman O \& Aperia A 2003 Na,K-ATPase as a signal transducer. Annals of the New York Academy of Sciences 986 489-496. (doi:10.1111/j.1749-6632. 2003.tb07233.x)

Aizman O, Uhlen P, Lal M, Brismar H \& Aperia A 2001 Ouabain, a steroid hormone that signals with slow calcium oscillations. PNAS 98 13420-13424. (doi:10.1073/pnas.221315298)

Akera T 1977 Membrane adenosinetriphosphatase: a digitalis receptor? Science 198 569-574. (doi:10.1126/science.144320)

Akera T \& Brody TM 1977 The role of $\mathrm{Na}^{+}, \mathrm{K}^{+}$-ATPase in the inotropic action of digitalis. Pharmacological Reviews 29 187-220.

Akera T \& Ng YC 1991 Digitalis sensitivity of $\mathrm{Na}^{+}, \mathrm{K}^{+}$-ATPase, myocytes and the heart. Life Sciences 48 97-106. (doi:10.1016/00243205(91)90402-W)

Anderson DE, Fedorova OV, Morrell CH, Longo DL, Kashkin VA, Metzler JD, Bagrov AY \& Lakatta EG 2008 Endogenous sodium pump inhibitors and age-associated increases in salt sensitivity of blood pressure in normotensives. American Journal of Physiology. Regulatory, Integrative and Comparative Physiology 294 R1248-R1254. (doi:10.1152/ajpregu.00782.2007)

Andersson RM, Aizman O, Aperia A \& Brismar H 2004 Modulation of $\mathrm{Na}^{+}, \mathrm{K}^{+}$-ATPase activity is of importance for RVD. Acta Physiologica Scandinavica 180 329-334. (doi:10.1111/j.1365-201X.2003.01256.x)

Apel A, Rachel P, Cohen O \& Mayan H 2013 Digoxin-associated decrease in parathyroid hormone (PTH) concentrations in patients with atrial fibrillation. European Journal of Clinical Investigation 43 152-158. (doi:10.1111/eci.12026)

Aperia A 2007 New roles for an old enzyme: Na,K-ATPase emerges as an interesting drug target. Journal of Internal Medicine 261 44-52. (doi:10.1111/j.1365-2796.2006.01745.x)

Aperia A 20122011 Homer Smith Award: to serve and protect: classic and novel roles for $\mathrm{Na}^{+}, \mathrm{K}^{+}$-adenosine triphosphatase. Journal of the American Society of Nephrology 23 1283-1290. (doi:10.1681/ASN. 2012010102)

Askari A, Kakar SS \& Huang WH 1988 Ligand binding sites of the ouabaincomplexed $\left(\mathrm{Na}^{+}+\mathrm{K}^{+}\right)$-ATPase. Journal of Biological Chemistry 263 235-242.

Averina IV, Tapilskaya NI, Reznik VA, Frolova EV, Fedorova OV, Lakatta EG \& Bagrov AY 2006 Endogenous Na/K-ATPase inhibitors in patients with preeclampsia. Cellular and Molecular Biology 52 19-23.

Published by Bioscientifica Ltd 
Bagrov AY \& Shapiro JI 2008 Endogenous digitalis: pathophysiologic roles and therapeutic applications. Nature Clinical Practice. Nephrology 4 378-392. (doi:10.1038/ncpneph0848)

Bagrov AY, Dmitrieva RI, Fedorova OV, Kazakov GP, Roukoyatkina NI \& Shpen VM 1996 Endogenous marinobufagenin-like immunoreactive substance. A possible endogenous $\mathrm{Na}$, K-ATPase inhibitor with vasoconstrictor activity. American Journal of Hypertension 9 982-990. (doi:10.1016/0895-7061(96)00148-3)

Bagrov YY, Manusova NB, Egorova IA, Fedorova OV \& Bagrov AY 2005 Endogenous digitalis-like ligands and $\mathrm{Na} / \mathrm{K}-\mathrm{ATP}$ ase inhibition in experimental diabetes mellitus. Frontiers in Bioscience 10 2257-2262. (doi:10.2741/1695)

Bagrov AY, Shapiro JI \& Fedorova OV 2009 Endogenous cardiotonic steroids: physiology, pharmacology, and novel therapeutic targets. Pharmacological Reviews 61 9-38. (doi:10.1124/pr.108.000711)

Bai Y, Morgan EE, Giovannucci DR, Pierre SV, Philipson KD, Askari A \& Liu L 2013 Different roles of the cardiac $\mathrm{Na}^{+} / \mathrm{Ca}^{2+}$-exchanger in ouabaininduced inotropy, cell signaling, and hypertrophy. American Journal of Physiology. Heart and Circulatory Physiology 304 H427-H435. (doi:10.1152/ajpheart.00462.2012)

Barwe SP, Anilkumar G, Moon SY, Zheng Y, Whitelegge JP, Rajasekaran SA \& Rajasekaran AK 2005 Novel role for Na,K-ATPase in phosphatidylinositol 3-kinase signaling and suppression of cell motility. Molecular Biology of the Cell 16 1082-1094. (doi:10.1091/mbc.E04-05-0427)

Beguin P, Hasler U, Beggah A \& Geering K 1998a Regulation of expression and function by subunits of oligomeric P-type ATPases. Acta Physiologica Scandinavica. Supplementum 643 283-287.

Beguin P, Hasler U, Beggah A, Horisberger JD \& Geering K $1998 b$ Membrane integration of $\mathrm{Na}$,K-ATPase $\alpha$-subunits and $\beta$-subunit assembly. Journal of Biological Chemistry 273 24921-24931.

Bignami E, Casamassima N, Frati E, Lanzani C, Corno L, Alfieri O, Gottlieb S, Simonini M, Shah KB, Mizzi A et al. 2013 Preoperative endogenous ouabain predicts acute kidney injury in cardiac surgery patients. Critical Care Medicine 41 744-755. (doi:10.1097/CCM.0b013e3182741599)

Blanco G $2005 \mathrm{Na}$,K-ATPase subunit heterogeneity as a mechanism for tissue-specific ion regulation. Seminars in Nephrology 25 292-303. (doi:10.1016/j.semnephrol.2005.03.004)

Blanco G \& Wallace DP 2013 Novel role of ouabain as a cystogenic factor in autosomal dominant polycystic kidney disease. American Journal of Physiology. Renal Physiology 305 F797-F812. (doi:10.1152/ajprenal. 00248.2013)

Blaustein MP \& Hamlyn JM 2010 Signaling mechanisms that link salt retention to hypertension: endogenous ouabain, the $\mathrm{Na}^{+}$pump, the $\mathrm{Na}^{+} / \mathrm{Ca}^{2+}$ exchanger and TRPC proteins. Biochimica et Biophysica Acta 1802 1219-1229. (doi:10.1016/j.bbadis.2010.02.011)

Blaustein MP, Juhaszova M \& Golovina VA 1998 The cellular mechanism of action of cardiotonic steroids: a new hypothesis. Clinical and Experimental Hypertension 20 691-703. (doi:10.3109/ 10641969809053247)

Blaustein MP, Zhang J, Chen L \& Hamilton BP 2006 How does salt retention raise blood pressure? American Journal of Physiology. Regulatory, Integrative and Comparative Physiology 290 R514-R523. (doi:10.1152/ajpregu.00819.2005)

Blaustein MP, Zhang J, Chen L, Song H, Raina H, Kinsey SP, Izuka M, Iwamoto T, Kotlikoff MI, Lingrel JB et al. 2009 The pump, the exchanger, and endogenous ouabain: signaling mechanisms that link salt retention to hypertension. Hypertension 53 291-298. (doi:10.1161/ HYPERTENSIONAHA.108.119974)

Blaustein MP, Leenen FH, Chen L, Golovina VA, Hamlyn JM, Pallone TL, Van Huysse JW, Zhang J \& Wier WG 2012 How $\mathrm{NaCl}$ raises blood pressure: a new paradigm for the pathogenesis of salt-dependent hypertension. American Journal of Physiology. Heart and Circulatory Physiology 302 H1031-H1049. (doi:10.1152/ajpheart.00899.2011)

Bluschke V, Bonn R \& Greeff K 1976 Increase in the $\left(\mathrm{Na}^{+}+\mathrm{K}^{+}\right)$-ATPase activity in heart muscle after chronic treatment with digitoxin or potassium deficient diet. European Journal of Pharmacology 37 189-191. (doi:10.1016/0014-2999(76)90021-2)

Boulanger BR, Lilly MP, Hamlyn JM, Laredo J, Shurtleff D \& Gann DS 1993 Ouabain is secreted by the adrenal gland in awake dogs. American Journal of Physiology 264 E413-E419.

Bourgoignie J, Klahr S \& Bricker NS 1971 Inhibition of transepithelial sodium transport in the frog skin by a low molecular weight fraction of uremic serum. Journal of Clinical Investigation 50 303-311. (doi:10.1172/JCI106495)

Brashear A, Cook JF, Hill DF, Amponsah A, Snively BM, Light L, Boggs N, Suerken CK, Stacy M, Ozelius L et al. 2012 Psychiatric disorders in rapidonset dystonia-parkinsonism. Neurology 79 1168-1173. (doi:10.1212/ WNL.0b013e3182698d6c)

Bricker NS 1972 On the pathogenesis of the uremic state. An exposition of the trade-off hypothesis. New England Journal of Medicine $\mathbf{2 8 6}$ 1093-1099. (doi:10.1056/NEJM197205182862009)

Bricker NS \& Klahr S 1970 The physiologic basis of sodium excretion and diuresis. Advances in Internal Medicine 16 17-41.

Bricker NS, Klahr S, Purkerson M, Schultze RG, Avioli LV \& Birge SJ 1968 In vitro assay for a humoral substance present during volume expansion and uraemia. Nature 219 1058-1059. (doi:10.1038/2191058a0)

Bricker NS, Bourgoignie JJ \& Klahr S 1970 A humoral inhibitor of sodium transport in uremic serum. A potential toxin? Archives of Internal Medicine 126 860-864. (doi:10.1001/archinte.1970.00310110130023)

Bricker NS, Bourgoignie J, Weber H, Schmidt RW \& Slatopolsky E 1972 Pathogenesis of the uremic state: a new perspective. Advances in Nephrology from the Necker Hospital 2 263-276.

Bricker NS, Zea L, Shapiro M, Sanclemente E \& Shankel S 1993 Biologic and physical characteristics of the non-peptidic, non-digitalis-like natriuretic hormone. Kidney International 44 937-947. (doi:10.1038/ ki.1993.335)

Brody TM \& Akera T 1977 Relations among $\mathrm{Na}^{+}, \mathrm{K}^{+}$-ATPase activity, sodium pump activity, transmembrane sodium movement, and cardiac contractility. Federation Proceedings 36 2219-2224.

Brown TE, Acheson GH \& Grupp G 1962 The saturated-lactone glycoside dihydro-ouabain: effects on potassium balance of the dog heart. Journal of Pharmacology and Experimental Therapeutics 136 107-113.

Brown EM, Jones P \& Adragna N 1983 Effects of ouabain on $\left[{ }^{3} \mathrm{H}\right]$ ouabain binding, ${ }^{86} \mathrm{Rb}$ uptake, cellular sodium and potassium, and parathyroid hormone secretion in dispersed bovine parathyroid cells. Endocrinology 113 371-378. (doi:10.1210/endo-113-1-371)

Brown EM, Watson EJ, Thatcher JG, Koletsky R, Dawson-Hughes BF, Posillico JT \& Shoback DM 1987 Ouabain and low extracellular potassium inhibit PTH secretion from bovine parathyroid cells by a mechanism that does not involve increases in the cytosolic calcium concentration. Metabolism 36 36-42. (doi:10.1016/ 0026-0495(87)90060-6)

Burlaka I, Liu XL, Rebetz J, Arvidsson I, Yang L, Brismar H, Karpman D \& Aperia A 2013 Ouabain protects against shiga toxin-triggered apoptosis by reversing the imbalance between Bax and Bcl-xL. Journal of the American Society of Nephrology 24 1413-1423. (doi:10.1681/ASN. 2012101044)

Bystriansky JS \& Kaplan JH 2007 Sodium pump localization in epithelia. Journal of Bioenergetics and Biomembranes 39 373-378. (doi:10.1007/ s10863-007-9100-3)

Cai T, Wang H, Chen Y, Liu L, Gunning WT, Quintas LE \& Xie ZJ 2008 Regulation of caveolin-1 membrane trafficking by the Na/K-ATPase. Journal of Cell Biology 182 1153-1169. (doi:10.1083/jcb.200712022)

Choi YR \& Akera T 1977 Kinetics studies on the interaction between ouabain and $\left(\mathrm{Na}^{+}, \mathrm{K}^{+}\right)$-ATPase. Biochimica et Biophysica Acta 481 648-659. (doi:10.1016/0005-2744(77)90298-4)

Cohen I, Daut J \& Noble D 1976 An analysis of the actions of low concentrations of ouabain on membrane currents in Purkinje fibres. Journal of Physiology 260 75-103.

Contreras RG, Shoshani L, Flores-Maldonado C, Lazaro A \& Cereijido M 1999 Relationship between $\mathrm{Na}^{+}, \mathrm{K}^{+}$-ATPase and cell attachment. Journal of Cell Science 112 4223-4232. http://joe.endocrinology-journals.org DOI: 10.1530/JOE-13-0613 (c) 2014 Society for Endocrinology Printed in Great Britain 
Contreras RG, Flores-Maldonado C, Lazaro A, Shoshani L, Flores-Benitez D, Larre I \& Cereijido M 2004 Ouabain binding to $\mathrm{Na}^{+}, \mathrm{K}^{+}$-ATPase relaxes cell attachment and sends a specific signal (NACos) to the nucleus. Journal of Membrane Biology 198 147-158. (doi:10.1007/s00232-0040670-2)

Contreras RG, Flores-Beni Tez D, Flores-Maldonado C, Larre I, Shoshani L \& Cereijido $\mathrm{M} 2006 \mathrm{Na}^{+}, \mathrm{K}^{+}$-ATPase and hormone ouabain:new roles for an old enzyme and an old inhibitor. Cellular and Molecular Biology 52 31-40.

Cow D 1914 The suprarenal bodies and diuresis. Journal of Physiology 48 443-452.

Craver JL \& Valdes R Jr 1983 Anomalous serum digoxin concentrations in uremia. Annals of Internal Medicine 98 483-484. (doi:10.7326/00034819-98-4-483)

Dmitrieva RI \& Doris PA 2003 Ouabain is a potent promoter of growth and activator of ERK1/2 in ouabain-resistant rat renal epithelial cells. Journal of Biological Chemistry 278 28160-28166. (doi:10.1074/jbc. M303768200)

Dmitrieva RI, Lalli E \& Doris PA 2005 Regulation of adrenocortical cardiotonic steroid production by dopamine and PKA signaling. Frontiers in Bioscience 10 2489-2495. (doi:10.2741/1713)

Dong XH, Komiyama Y, Nishimura N, Masuda M \& Takahashi H 2004 Nanomolar level of ouabain increases intracellular calcium to produce nitric oxide in rat aortic endothelial cells. Clinical and Experimental Pharmacology and Physiology 31 276-283. (doi:10.1111/j.1440-1681. 2004.03995.x)

Donnet C \& Sweadner KJ 2003 The mechanism of Na-K interaction on Na,K-ATPase. Annals of the New York Academy of Sciences 986 249-251. (doi:10.1111/j.1749-6632.2003.tb07174.x)

Doris PA, Kilgore MW, Durham D, Alberts D \& Stocco DM 1989 An endogenous digitalis-factor derived from the adrenal gland: studies of adrenocortical tumor cells. Endocrinology 125 2580-2586. (doi:10.1210/endo-125-5-2580)

El-Mallakh RS, Miller J, Valdes R Jr, Cassis TB \& Li R 2007 Digoxin-like immunoreactive factor in human cerebrospinal fluid. Journal of Neuropsychiatry and Clinical Neurosciences 19 91. (doi:10.1176/appi.neuropsych.19.1.91)

Fedorova OV, Doris PA \& Bagrov AY 1998 Endogenous marinobufageninlike factor in acute plasma volume expansion. Clinical and Experimental Hypertension 20 581-591. (doi:10.3109/10641969809053236)

Fedorova OV, Agalakova NI, Talan MI, Lakatta EG \& Bagrov AY $2005 a$ Brain ouabain stimulates peripheral marinobufagenin via angiotensin II signalling in NaCl-loaded Dahl-S rats. Journal of Hypertension 23 1515-1523. (doi:10.1097/01.hjh.0000174969.79836.8b)

Fedorova OV, Kolodkin NI, Agalakova NI, Namikas AR, Bzhelyansky A, St-Louis J, Lakatta EG \& Bagrov AY 2005b Antibody to marinobufagenin lowers blood pressure in pregnant rats on a high $\mathrm{NaCl}$ intake. Journal of Hypertension 23 835-842. (doi:10.1097/01.hjh.0000163153.27954.33)

Fedorova OV, Shapiro JI \& Bagrov AY 2010a Endogenous cardiotonic steroids and salt-sensitive hypertension. Biochimica et Biophysica Acta 1802 1230-1236. (doi:10.1016/j.bbadis.2010.03.011)

Fedorova OV, Tapilskaya NI, Bzhelyansky AM, Frolova EV, Nikitina ER, Reznik VA, Kashkin VA \& Bagrov AY $2010 b$ Interaction of digibind with endogenous cardiotonic steroids from preeclamptic placentae. Journal of Hypertension 28 361-366. (doi:10.1097/HJH. Ob013e328333226c)

Fedorova OV, Kashkin VA, Zakharova IO, Lakatta EG \& Bagrov AY 2012 Age-associated increase in salt sensitivity is accompanied by a shift in the atrial natriuretic peptide modulation of the effect of marinobufagenin on renal and vascular sodium pump. Journal of Hypertension $\mathbf{3 0}$ 1817-1826. (doi:10.1097/HJH.0b013e328356399b)

Ferrandi M, Manunta P, Balzan S, Hamlyn JM, Bianchi G \& Ferrari P 1997 Ouabain-like factor quantification in mammalian tissues and plasma: comparison of two independent assays. Hypertension 30 886-896. (doi:10.1161/01.HYP.30.4.886)

Ferrari P 2010 Rostafuroxin: an ouabain-inhibitor counteracting specific forms of hypertension. Biochimica et Biophysica Acta 1802 1254-1258. (doi:10.1016/j.bbadis.2010.01.009)
Ferrari P, Ferrandi M, Valentini G \& Bianchi G 2006 Rostafuroxin: an ouabain antagonist that corrects renal and vascular $\mathrm{Na}^{+}-\mathrm{K}^{+}$- ATPase alterations in ouabain and adducin-dependent hypertension. American Journal of Physiology. Regulatory, Integrative and Comparative Physiology 290 R529-R535. (doi:10.1152/ajpregu.00518.2005)

Fontana JM, Burlaka I, Khodus G, Brismar H \& Aperia A 2013 Calcium oscillations triggered by cardiotonic steroids. FEBS Journal $\mathbf{2 8 0}$ 5450-5455. (doi:10.1111/febs.12448)

Forbush B III, Kaplan JH \& Hoffman JF 1978 Characterization of a new photoaffinity derivative of ouabain: labeling of the large polypeptide and of a proteolipid component of the $\mathrm{Na}, \mathrm{K}-\mathrm{ATPase}$. Biochemistry 17 3667-3676. (doi:10.1021/bi00610a037)

Gao J, Wymore RS, Wang Y, Gaudette GR, Krukenkamp IB, Cohen IS \& Mathias RT 2002 Isoform-specific stimulation of cardiac $\mathrm{Na} / \mathrm{K}$ pumps by nanomolar concentrations of glycosides. Journal of General Physiology 119 297-312. (doi:10.1085/jgp.20028501)

Geering K 1991 The functional role of the $\beta$-subunit in the maturation and intracellular transport of Na,K-ATPase. FEBS Letters 285 189-193. (doi:10.1016/0014-5793(91)80801-9)

Geering K 2008 Functional roles of Na,K-ATPase subunits. Current Opinion in Nephrology and Hypertension 17 526-532. (doi:10.1097/MNH. Ob013e3283036cbf)

Glynn IM 1956 Sodium and potassium movements in human red cells. Journal of Physiology 134 278-310.

Gonick HC, Ding Y, Vaziri ND, Bagrov AY \& Fedorova OV 1998 Simultaneous measurement of marinobufagenin, ouabain, and hypertension-associated protein in various disease states. Clinical and Experimental Hypertension 20 617-627. (doi:10.3109/ 10641969809053240)

Goto A, Yamada K, Yagi N, Yoshioka M \& Sugimoto T 1992 Physiology and pharmacology of endogenous digitalis-like factors. Pharmacological Reviews 44 377-399.

Graves SW, Brown B \& Valdes R Jr 1983 An endogenous digoxin-like substance in patients with renal impairment. Annals of Internal Medicine 99 604-608. (doi:10.7326/0003-4819-99-5-604)

Graves SW, Valdes R Jr, Brown BA, Knight AB \& Craig HR 1984 Endogenous digoxin-immunoreactive substance in human pregnancies. Journal of Clinical Endocrinology and Metabolism 58 748-751. (doi:10.1210/ jcem-58-4-748)

Greeff K \& Fox AA 1984 Cardiac glycosides and sodium/potassium-ATPase. Basic Research in Cardiology 79(Suppl) 16-20.

Grider G, El-Mallakh RS, Huff MO, Buss TJ, Miller J \& Valdes R Jr 1999 Endogenous digoxin-like immunoreactive factor (DLIF) serum concentrations are decreased in manic bipolar patients compared to normal controls. Journal of Affective Disorders 54 261-267. (doi:10.1016/ S0165-0327(98)00208-0)

Hamlyn JM \& Manunta P 2011 Endogenous ouabain: a link between sodium intake and hypertension. Current Hypertension Reports 13 14-20. (doi:10.1007/s11906-010-0161-z)

Hamlyn JM, Ringel R, Schaeffer J, Levinson PD, Hamilton BP, Kowarski AA $\&$ Blaustein MP 1982 A circulating inhibitor of $\left(\mathrm{Na}^{+}+\mathrm{K}^{+}\right)$ATPase associated with essential hypertension. Nature $300650-652$. (doi:10.1038/300650a0)

Hamlyn JM, Schenden JA, Zyren J \& Baczynskyj L 1987 Purification and characterization of digitalis-like factors from human plasma. Hypertension 10 I71-I77. (doi:10.1161/01.HYP.10.5_Pt_2.I71)

Hamlyn JM, Harris DW \& Ludens JH 1989 Digitalis-like activity in human plasma. Purification, affinity, and mechanism. Journal of Biological Chemistry 264 7395-7404.

Hamlyn JM, Blaustein MP, Bova S, DuCharme DW, Harrism DW, Mandel F, Mathews WR \& Ludens JH 1991 Identification and characterization of a ouabain-like compound from human plasma. PNAS 88 6259-6263. (doi:10.1073/pnas.88.14.6259)

Hamlyn JM, Hamilton BP \& Manunta P 1996 Endogenous ouabain, sodium balance and blood pressure: a review and a hypothesis. Journal of Hypertension 14 151-167. (doi:10.1097/00004872-199602000-00002) 
Hamlyn JM, Lu ZR, Manunta P, Ludens JH, Kimura K, Shah JR, Laredo J, Hamilton JP, Hamilton MJ \& Hamilton BP 1998 Observations on the nature, biosynthesis, secretion and significance of endogenous ouabain. Clinical and Experimental Hypertension 20 523-533. (doi:10.3109/10641969809053230)

Hasler U, Wang X, Crambert G, Beguin P, Jaisser F, Horisberger JD \& Geering K 1998 Role of $\beta$-subunit domains in the assembly, stable expression, intracellular routing, and functional properties of $\mathrm{Na}, \mathrm{K}-\mathrm{ATPase}$. Journal of Biological Chemistry 273 30826-30835.

Holthouser KA, Mandal A, Merchant ML, Schelling JR, Delamere NA, Valdes RR Jr, Tyagi SC, Lederer ED \& Khundmiri SJ 2010 Ouabain stimulates Na-K-ATPase through a sodium/hydrogen exchanger-1 (NHE-1)-dependent mechanism in human kidney proximal tubule cells. American Journal of Physiology. Renal Physiology 299 F77-F90. (doi:10.1152/ajprenal.00581.2009)

Jansson K, Nguyen AN, Magenheimer BS, Reif GA, Aramadhaka LR, Bello-Reuss E, Wallace DP, Calvet JP \& Blanco G 2012 Endogenous concentrations of ouabain act as a cofactor to stimulate fluid secretion and cyst growth of in vitro ADPKD models via cAMP and EGFR-Src-MEK pathways. American Journal of Physiology. Renal Physiology $\mathbf{3 0 3}$ F982-F990. (doi:10.1152/ajprenal.00677.2011)

Jansson K, Magenheimer BS, Maser RL, Calvet JP \& Blanco G 2013 Overexpression of the polycystin-1 C-tail enhances sensitivity of M-1 cells to ouabain. Journal of Membrane Biology 246 581-590. (doi:10.1007/s00232-013-9573-4)

Jimenez T, Sanchez G, Wertheimer E \& Blanco G 2010 Activity of the Na,KATPase $\alpha 4$ isoform is important for membrane potential, intracellular $\mathrm{Ca}^{2+}$, and $\mathrm{pH}$ to maintain motility in rat spermatozoa. Reproduction 139 835-845. (doi:10.1530/REP-09-0495)

Jimenez T, McDermott JP, Sanchez G \& Blanco G $2011 a$ Na,K-ATPase $\alpha 4$ isoform is essential for sperm fertility. PNAS 108 644-649. (doi:10. 1073/pnas.1016902108)

Jimenez T, Sanchez G, McDermott JP, Nguyen AN, Kumar TR \& Blanco G $2011 b$ Increased expression of the Na,K-ATPase $\alpha 4$ isoform enhances sperm motility in transgenic mice. Biology of Reproduction 84 153-161. (doi:10.1095/biolreprod.110.087064)

Jimenez T, Sanchez G \& Blanco G 2012 Activity of the Na,K-ATPase $\alpha 4$ isoform is regulated during sperm capacitation to support sperm motility. Journal of Andrology 33 1047-1057. (doi:10.2164/jandrol.111. 015545)

Jorgensen PL \& Skou JC 1969 Preparation of highly active $\left(\mathrm{Na}^{+}+\mathrm{K}^{+}\right)$ATPase from the outer medulla of rabbit kidney. Biochemical and Biophysical Research Communications 37 39-46. (doi:10.1016/0006291X(69)90877-8)

Jortani SA \& Valdes R Jr 1997 Digoxin and its related endogenous factors. Critical Reviews in Clinical Laboratory Sciences 34 225-274. (doi:10.3109/ 10408369708998094)

Kanai R, Ogawa H, Vilsen B, Cornelius F \& Toyoshima C 2013 Crystal structure of a Na${ }^{+}$-bound $\mathrm{Na}^{+}, \mathrm{K}^{+}$-ATPase preceding the E1P state. Nature 502 201-206. (doi:10.1038/nature12578)

Kaplan JH 2002 Biochemistry of Na,K-ATPase. Annual Review of Biochemistry 71 511-535. (doi:10.1146/annurev.biochem.71.102201.141218)

Kawamura A, Guo J, Itagaki Y, Bell C, Wang Y, Haupert GT Jr, Magil S, Gallagher RT, Berova N \& Nakanishi K 1999 On the structure of endogenous ouabain. PNAS 96 6654-6659. (doi:10.1073/pnas.96. 12.6654)

Kennedy DJ, Vetteth S, Periyasamy SM, Kanj M, Fedorova L, Khouri S, Kahaleh MB, Xie Z, Malhotra D, Kolodkin NI et al. 2006 Central role for the cardiotonic steroid marinobufagenin in the pathogenesis of experimental uremic cardiomyopathy. Hypertension 47 488-495. (doi:10.1161/01.HYP.0000202594.82271.92)

Kennedy DJ, Elkareh J, Shidyak A, Shapiro AP, Smaili S, Mutgi K, Gupta S, Tian J, Morgan E, Khouri S et al. 2008 Partial nephrectomy as a model for uremic cardiomyopathy in the mouse. American Journal of Physiology. Renal Physiology 294 F450-F454. (doi:10.1152/ajprenal. 00472.2007)
Khodus GR, Kruusmagi M, Li J, Liu XL \& Aperia A 2011 Calcium signaling triggered by ouabain protects the embryonic kidney from adverse developmental programming. Pediatric Nephrology 26 1479-1482. (doi:10.1007/s00467-011-1816-y)

Khundmiri SJ, Metzler MA, Ameen M, Amin V, Rane MJ \& Delamere NA 2006 Ouabain induces cell proliferation through calcium-dependent phosphorylation of Akt (protein kinase B) in opossum kidney proximal tubule cells. American Journal of Physiology. Cell Physiology 291 C1247-C1257. (doi:10.1152/ajpcell.00593.2005)

Khundmiri SJ, Amin V, Henson J, Lewis J, Ameen M, Rane MJ \& Delamere NA 2007 Ouabain stimulates protein kinase B (Akt) phosphorylation in opossum kidney proximal tubule cells through an ERK-dependent pathway. American Journal of Physiology. Cell Physiology 293 C1171-C1180. (doi:10.1152/ajpcell.00535.2006)

Khundmiri SJ, Salyer SA, Farmer B, Qipshidze N, Murray RD, Clark BJ, Xie Z, Pressley TA \& Lederer ED 2014 Structural determinants for the ouabainstimulated increase in Na-K ATPase activity. Biochimica et Biophysica Acta 1843 1089-1102. (doi:10.1016/j.bbamcr.2014.02.005)

Kitano S, Morimoto S, Nishibe A, Fukuo K, Hirotani A, Nakahashi T, Yasuda O \& Ogihara T 1998 Exogenous ouabain is accumulated in the adrenals and mimics the kinetics of endogenous digitalis-like factor in rats. Hypertension Research 21 47-56. (doi:10.1291/hypres.21.47)

Klaus W \& Lee KS 1969 Influence of cardiac glycosides on calcium binding in muscle subcellular components. Journal of Pharmacology and Experimental Therapeutics 166 68-76.

Kolmakova EV, Haller ST, Kennedy DJ, Isachkina AN, Budny GV, Frolova EV, Piecha G, Nikitina ER, Malhotra D, Fedorova OV et al. 2011 Endogenous cardiotonic steroids in chronic renal failure. Nephrology, Dialysis, Transplantation 26 2912-2919. (doi:10.1093/ndt/gfq772)

Kometiani P, Li J, Gnudi L, Kahn BB, Askari A \& Xie Z 1998 Multiple signal transduction pathways link $\mathrm{Na}^{+} / \mathrm{K}^{+}$-ATPase to growth-related genes in cardiac myocytes. The roles of Ras and mitogen-activated protein kinases. Journal of Biological Chemistry 273 15249-15256. (doi:10.1074/ jbc.273.24.15249)

Kometiani P, Liu L \& Askari A 2005 Digitalis-induced signaling by $\mathrm{Na}^{+}$/ $\mathrm{K}^{+}$-ATPase in human breast cancer cells. Molecular Pharmacology 67 929-936. (doi:10.1124/mol.104.007302)

Komiyama Y, Nishimura N, Munakata M, Okuda K, Nishino N, Kosaka C, Masuda M, Mori T, Matsuda T \& Takahashi H 1999 Increases in plasma ouabainlike immunoreactivity during surgical extirpation of pheochromocytoma. Hypertension Research 22 135-139. (doi:10.1291/hypres.22.135)

Komiyama Y, Nishimura N, Munakata M, Mori T, Okuda K, Nishino N, Hirose S, Kosaka C, Masuda M \& Takahashi H 2001 Identification of endogenous ouabain in culture supernatant of PC12 cells. Journal of Hypertension 19 229-236. (doi:10.1097/00004872-200102000-00009)

Lackner TE, Lau BW, Parvin C \& Valdes R Jr 1988 Endogenous digoxin-like immunoreactivity in elderly patients with normal serum creatinine concentrations. Clinical Pharmacology 7 449-453.

Laursen M, Yatime L, Nissen P \& Fedosova NU 2013 Crystal structure of the high-affinity $\mathrm{Na}^{+}, \mathrm{K}^{+}$-ATPase-ouabain complex with $\mathrm{Mg}^{2+}$ bound in the cation binding site. PNAS 110 10958-10963. (doi:10.1073/pnas. 1222308110)

Lee KS \& Klaus W 1971 The subcellular basis for the mechanism of inotropic action of cardiac glycosides. Pharmacological Reviews 23 193-261.

Li J, Zelenin S, Aperia A \& Aizman O 2006 Low doses of ouabain protect from serum deprivation-triggered apoptosis and stimulate kidney cell proliferation via activation of NF- $\mathrm{B}$. Journal of the American Society of Nephrology 17 1848-1857. (doi:10.1681/ASN.2005080894)

Li Z, Cai T, Tian J, Xie JX, Zhao X, Liu L, Shapiro JI \& Xie Z 2009 NaKtide, a $\mathrm{Na} / \mathrm{K}-\mathrm{ATPa}$-derived peptide Src inhibitor, antagonizes ouabainactivated signal transduction in cultured cells. Journal of Biological Chemistry 284 21066-21076. (doi:10.1074/jbc.M109.013821)

Li J, Khodus GR, Kruusmagi M, Kamali-Zare P, Liu XL, Eklof AC, Zelenin S, Brismar H \& Aperia A 2010 Ouabain protects against adverse developmental programming of the kidney. Nature Communications 142. (doi:10.1038/ncomms1043) 
Liang M, Cai T, Tian J, Qu W \& Xie ZJ 2006 Functional characterization of Src-interacting Na/K-ATPase using RNA interference assay. Journal of Biological Chemistry 281 19709-19719. (doi:10.1074/jbc.M512240200)

Lingrel JB 2010 The physiological significance of the cardiotonic steroid/ouabain-binding site of the Na,K-ATPase. Annual Review of Physiology 72 395-412. (doi:10.1146/annurev-physiol-021909-135725)

Lingrel JB \& Kuntzweiler T $1994 \mathrm{Na}^{+}, \mathrm{K}^{+}$-ATPase. Journal of Biological Chemistry 269 19659-19662.

Liu L \& Askari A 2006 On the importance and mechanism of amplification of digitalis signal through $\mathrm{Na}^{+} / \mathrm{K}^{+}$-ATPase. Cellular and Molecular Biology 52 28-30.

Liu J \& Xie ZJ 2010 The sodium pump and cardiotonic steroids-induced signal transduction protein kinases and calcium-signaling microdomain in regulation of transporter trafficking. Biochimica et Biophysica Acta 1802 1237-1245. (doi:10.1016/j.bbadis.2010.01.013)

Liu J, Tian J, Haas M, Shapiro JI, Askari A \& Xie Z 2000 Ouabain interaction with cardiac $\mathrm{Na}^{+} / \mathrm{K}^{+}$-ATPase initiates signal cascades independent of changes in intracellular $\mathrm{Na}^{+}$and $\mathrm{Ca}^{2+}$ concentrations. Journal of Biological Chemistry 275 27838-27844. (doi:10.1074/jbc.M002950200)

Liu XL, Miyakawa A, Aperia A \& Krieger P 2007a Na,K-ATPase generates calcium oscillations in hippocampal astrocytes. Neuroreport 18 597-600. (doi:10.1097/WNR.0b013e3280b07bc9)

Liu L, Zhao X, Pierre SV \& Askari A 2007b Association of PI3K-Akt signaling pathway with digitalis-induced hypertrophy of cardiac myocytes. American Journal of Physiology. Cell Physiology 293 C1489-C1497. (doi:10.1152/ajpcell.00158.2007)

Liu L, Ivanov AV, Gable ME, Jolivel F, Morrill GA \& Askari A 2011 Comparative properties of caveolar and noncaveolar preparations of kidney $\mathrm{Na}^{+} / \mathrm{K}^{+}$-ATPase. Biochemistry 50 8664-8673. (doi:10.1021/ bi2009008)

Lopatin DA, Ailamazian EK, Dmitrieva RI, Shpen VM, Fedorova OV, Doris PA \& Bagrov AY 1999 Circulating bufodienolide and cardenolide sodium pump inhibitors in preeclampsia. Journal of Hypertension 17 1179-1187. (doi:10.1097/00004872-199917080-00018)

Loreaux EL, Kaul B, Lorenz JN \& Lingrel JB 2008 Ouabain-sensitive $\alpha 1$ $\mathrm{Na}, \mathrm{K}-\mathrm{ATPase}$ enhances natriuretic response to saline load. Journal of the American Society of Nephrology 19 1947-1954. (doi:10.1681/ASN. 2008020174)

Lorenz JN, Loreaux EL, Dostanic-Larson I, Lasko V, Schnetzer JR, Paul RJ \& Lingrel JB 2008 ACTH-induced hypertension is dependent on the ouabain-binding site of the $\alpha_{2}-\mathrm{Na}^{+}-\mathrm{K}^{+}$-ATPase subunit. American Journal of Physiology. Heart and Circulatory Physiology 295 H273-H280. (doi:10.1152/ajpheart.00183.2008)

Lutsenko S \& Kaplan JH 1993 An essential role for the extracellular domain of the Na,K-ATPase $\beta$-subunit in cation occlusion. Biochemistry 32 6737-6743. (doi:10.1021/bi00077a029)

Malik N, Canfield VA, Beckers MC, Gros P \& Levenson R 1996 Identification of the mammalian $\mathrm{Na}, \mathrm{K}-\mathrm{ATP}$ ase $\beta 3$ subunit. Journal of Biological Chemistry 271 22754-22758. (doi:10.1074/jbc.271.37.22754)

Manunta P, Hamilton BP \& Hamlyn JM 2001a Structure-activity relationships for the hypertensinogenic activity of ouabain: role of the sugar and lactone ring. Hypertension 37 472-477. (doi:10.1161/01. HYP.37.2.472)

Manunta P, Messaggio E, Ballabeni C, Sciarrone MT, Lanzani C, Ferrandi M, Hamlyn JM, Cusi D, Galletti F \& Bianchi G 2001b Plasma ouabain-like factor during acute and chronic changes in sodium balance in essential hypertension. Hypertension 38 198-203. (doi:10.1161/01.HYP.38.2.198)

Manunta P, Hamilton BP \& Hamlyn JM 2006 Salt intake and depletion increase circulating levels of endogenous ouabain in normal men. American Journal of Physiology. Regulatory, Integrative and Comparative Physiology 290 R553-R559. (doi:10.1152/ajpregu.00648.2005)

Manunta P, Messaggio E, Casamassima N, Gatti G, Carpini SD, Zagato L \& Hamlyn JM 2010 Endogenous ouabain in renal $\mathrm{Na}^{+}$handling and related diseases. Biochimica et Biophysica Acta 1802 1214-1218. (doi:10.1016/j.bbadis.2010.03.001)
Martin DW 2005 Structure-function relationships in the $\mathrm{NA}^{+}{ }^{+} \mathrm{K}^{+}$-pump Seminars in Nephrology 25 282-291. (doi:10.1016/j.semnephrol.2005. 03.003)

el-Masri MA, Clark BJ, Qazzaz HM \& Valdes R Jr 2002 Human adrenal cells in culture produce both ouabain-like and dihydroouabain-like factors. Clinical Chemistry 48 1720-1730.

Masugi F, Ogihara T, Hasegawa T, Sakaguchi K \& Kumahara Y 1988 Normalization of high plasma level of ouabain-like immunoreactivity in primary aldosteronism after removal of adenoma. Journal of Human Hypertension 2 17-20.

Mathews WR, DuCharme DW, Hamlyn JM, Harris DW, Mandel F, Clark MA \& Ludens JH 1991 Mass spectral characterization of an endogenous digitalislike factor from human plasma. Hypertension 17 930-935. (doi:10.1161/01.HYP.17.6.930)

McDonough AA, Geering K \& Farley RA 1990 The sodium pump needs its $\beta$ subunit. FASEB Journal 4 1598-1605.

Mohammadi K, Kometiani P, Xie Z \& Askari A 2001 Role of protein kinase C in the signal pathways that link $\mathrm{Na}^{+} / \mathrm{K}^{+}$-ATPase to ERK1/2. Journal of Biological Chemistry 276 42050-42056. (doi:10.1074/jbc.M107892200)

Mohammadi K, Liu L, Tian J, Kometiani P, Xie Z \& Askari A 2003 Positive inotropic effect of ouabain on isolated heart is accompanied by activation of signal pathways that link $\mathrm{Na}^{+} / \mathrm{K}^{+}$-ATPase to $\mathrm{ERK}_{1 / 2}$. Journal of Cardiovascular Pharmacology 41 609-614. (doi:10.1097/ 00005344-200304000-00014)

Mohmand B, Malhotra DK \& Shapiro JI 2005 Uremic cardiomyopathy: role of circulating digitalis like substances. Frontiers in Bioscience $\mathbf{1 0}$ 2036-2044. (doi:10.2741/1679)

Morrill GA, Kostellow AB \& Askari A 2012 Caveolin-Na/K-ATPase interactions: role of transmembrane topology in non-genomic steroid signal transduction. Steroids 77 1160-1168. (doi:10.1016/j.steroids. 2012.04.012)

Morth JP, Pedersen BP, Toustrup-Jensen MS, Sorensen TL, Petersen J, Andersen B, Vilsen P \& Nissen P 2007 Crystal structure of the sodiumpotassium pump. Nature 450 1043-1049. (doi:10.1038/nature06419)

Morth JP, Poulsen H, Toustrup-Jensen MS, Schack VR, Egebjerg J, Andersen JP, Vilsen B \& Nissen P 2009 The structure of the $\mathrm{Na}^{+}, \mathrm{K}^{+}$-ATPase and mapping of isoform differences and disease-related mutations. Philosophical transactions of the Royal Society of London. Series B, Biological Sciences 364 217-227. (doi:10.1098/rstb.2008.0201)

Morth JP, Pedersen BP, Buch-Pedersen MJ, Andersen JP, Vilsen B, Palmgren MG $\&$ Nissen P 2011 A structural overview of the plasma membrane $\mathrm{Na}^{+}$, $\mathrm{K}^{+}$-ATPase and $\mathrm{H}^{+}$-ATPase ion pumps. Nature Reviews. Molecular Cell Biology 12 60-70. (doi:10.1038/nrm3031)

Nguyen AN, Wallace DP \& Blanco G 2007 Ouabain binds with high affinity to the Na,K-ATPase in human polycystic kidney cells and induces extracellular signal-regulated kinase activation and cell proliferation. Journal of the American Society of Nephrology 18 46-57. (doi:10.1681/ ASN.2006010086)

Nguyen AN, Jansson K, Sanchez G, Sharma M, Reif GA, Wallace DP \& Blanco G 2011 Ouabain activates the Na-K-ATPase signalosome to induce autosomal dominant polycystic kidney disease cell proliferation. American Journal of Physiology. Renal Physiology 301 F897-F906. (doi:10.1152/ajprenal.00095.2011)

Nicholls MG, Lewis LK, Yandle TG, Lord G, McKinnon W \& Hilton PJ 2009 Ouabain, a circulating hormone secreted by the adrenals, is pivotal in cardiovascular disease. Fact or fantasy? Journal of Hypertension 27 3-8. (doi:10.1097/HJH.0b013e32831101d1)

Ogawa H, Shinoda T, Cornelius F \& Toyoshima C 2009 Crystal structure of the sodium-potassium pump $\left(\mathrm{Na}^{+}, \mathrm{K}^{+}\right.$-ATPase $)$with bound potassium and ouabain. PNAS 106 13742-13747. (doi:10.1073/pnas.0907054106)

Pedersen BP, Buch-Pedersen MJ, Morth JP, Palmgren MG \& Nissen P 2007 Crystal structure of the plasma membrane proton pump. Nature $\mathbf{4 5 0}$ 1111-1114. (doi:10.1038/nature06417)

Peng M, Huang L, Xie Z, Huang WH \& Askari A 1996 Partial inhibition of $\mathrm{Na}^{+} / \mathrm{K}^{+}$-ATPase by ouabain induces the $\mathrm{Ca}^{2+}$-dependent expressions 
of early-response genes in cardiac myocytes. Journal of Biological Chemistry 271 10372-10378. (doi:10.1074/jbc.271.17.10372)

Perrin A, Brasmes B, Chambaz EM \& Defaye G 1997 Bovine adrenocortical cells in culture synthesize an ouabain-like compound. Molecular and Cellular Endocrinology 126 7-15. (doi:10.1016/S0303-7207(96)03964-0)

Pierdomenico SD, Bucci A, Manunta P, Rivera R, Ferrandi M, Hamlyn JM, Lapenna D, Cuccurullo F \& Mezzetti A 2001 Endogenous ouabain and hemodynamic and left ventricular geometric patterns in essential hypertension. American Journal of Hypertension 14 44-50. (doi:10.1016/ S0895-7061(00)01225-5)

Pierre SV \& Xie Z 2006 The Na,K-ATPase receptor complex: its organization and membership. Cell Biochemistry and Biophysics 46 303-316. (doi:10.1385/CBB:46:3:303)

Pierre SV, Sottejeau Y, Gourbeau JM, Sanchez G, Shidyak A \& Blanco G 2008 Isoform specificity of Na-K-ATPase-mediated ouabain signaling. American Journal of Physiology. Renal Physiology 294 F859-F866. (doi:10.1152/ajprenal.00089.2007)

Qazzaz HM \& Valdes R Jr 1996 Simultaneous isolation of endogenous digoxin-like immunoreactive factor, ouabain-like factor, and deglycosylated congeners from mammalian tissues. Archives of Biochemistry and Biophysics 328 193-200. (doi:10.1006/abbi.1996.0160)

Qazzaz HM, Goudy SL \& Valdes R Jr 1996a Deglycosylated products of endogenous digoxin-like immunoreactive factor in mammalian tissue. Journal of Biological Chemistry 271 8731-8737. (doi:10.1074/jbc.271. 15.8731)

Qazzaz HM, Jortani SA, Poole JM \& Valdes R Jr $1996 b$ Evidence for presence of a reduced form of digoxin-like immunoreactive factor (dihydroDLIF) in mammalian tissues. Clinical Chemistry 42 1092-1099.

Qazzaz HM, El-Masri MA \& Valdes R Jr 2000 Secretion of a lactonehydrogenated ouabain-like effector of sodium, potassium-adenosine triphosphatase activity by adrenal cells. Endocrinology 141 3200-3209. (doi:10.1210/endo.141.9.7664)

Qazzaz HM, Cao Z, Bolanowski DD, Clark BJ \& Valdes R Jr 2004 De novo biosynthesis and radiolabeling of mammalian digitalis-like factors. Clinical Chemistry 50 612-620. (doi:10.1373/clinchem.2003.022715)

Quintas LE, Pierre SV, Liu L, Bai Y, Liu X \& Xie ZJ 2010 Alterations of $\mathrm{Na}^{+} / \mathrm{K}^{+}$-ATPase function in caveolin-1 knockout cardiac fibroblasts. Journal of Molecular and Cellular Cardiology 49 525-531. (doi:10.1016/ j.yjmcc.2010.04.015)

Rajasekaran AK \& Rajasekaran SA 2003 Role of Na-K-ATPase in the assembly of tight junctions. American Journal of Physiology. Renal Physiology $\mathbf{2 8 5}$ F388-F396. (doi:10.1152/ajprenal.00439.2002)

Rajasekaran SA \& Rajasekaran AK 2009 Na,K-ATPase and epithelial tight junctions. Frontiers in Bioscience 14 2130-2148. (doi:10.2741/3367)

Rincon-Heredia R, Flores-Benitez D, Flores-Maldonado C, Bonilla-Delgado J, Garcia-Hernandez V, Verdejo-Torres O, Castillo AM, Larre I, PootHernandez AC, Franco M et al. 2014 Ouabain induces endocytosis and degradation of tight junction proteins through ERK1/2-dependent pathways. Experimental Cell Research 320 108-118. (doi:10.1016/ j.yexcr.2013.10.008)

Sanchez G, Nguyen AN, Timmerberg B, Tash JS \& Blanco G 2006 The $\mathrm{Na}, \mathrm{K}-\mathrm{ATPase} \alpha 4$ isoform from humans has distinct enzymatic properties and is important for sperm motility. Molecular Human Reproduction 12 565-576. (doi:10.1093/molehr/gal062)

Schack VR, Morth JP, Toustrup-Jensen MS, Anthonisen AN, Nissen P, Andersen JP \& Vilsen B 2008 Identification and function of a cytoplasmic $\mathrm{K}^{+}$site of the $\mathrm{Na}^{+}, \mathrm{K}^{+}$-ATPase. Journal of Biological Chemistry 283 27982-27990. (doi:10.1074/jbc.M803506200)

Schneider R, Antolovic R, Kost H, Sich B, Kirch U, Tepel M, Zidek W \& Schoner W 1998 a Proscillaridin a immunoreactivity: its purification, transport in blood by a specific binding protein and its correlation with blood pressure. Clinical and Experimental Hypertension 20 593-599. (doi:10.3109/10641969809053237)

Schneider R, Wray V, Nimtz M, Lehmann WD, Kirch U, Antolovic R \& Schoner W $1998 b$ Bovine adrenals contain, in addition to ouabain, a

http://joe.endocrinology-journals.org DOI: $10.1530 /$ JOE-13-0613
() 2014 Society for Endocrinology Printed in Great Britain second inhibitor of the sodium pump. Journal of Biological Chemistry 273 784-792. (doi:10.1074/jbc.273.2.784)

Schoner W 2002 Endogenous cardiac glycosides, a new class of steroid hormones. European Journal of Biochemistry 269 2440-2448. (doi:10.1046/j.1432-1033.2002.02911.x)

Schoner W \& Scheiner-Bobis G 2005 Endogenous cardiac glycosides: hormones using the sodium pump as signal transducer. Seminars in Nephrology 25 343-351. (doi:10.1016/j.semnephrol.2005.03.010)

Schoner W \& Scheiner-Bobis G 2007a Endogenous and exogenous cardiac glycosides and their mechanisms of action. American Journal of Cardiovascular Drugs 7 173-189. (doi:10.2165/00129784-20070703000004)

Schoner W \& Scheiner-Bobis G 2007b Endogenous and exogenous cardiac glycosides: their roles in hypertension, salt metabolism, and cell growth. American Journal of Physiology. Cell Physiology 293 C509-C536. (doi:10.1152/ajpcell.00098.2007)

Schoner W \& Scheiner-Bobis G 2008 Role of endogenous cardiotonic steroids in sodium homeostasis. Nephrology, Dialysis, Transplantation 23 2723-2729. (doi:10.1093/ndt/gfn325)

Schrier RW \& Berl T 1975 Nonosmolar factors affecting renal water excretion (first of two parts). New England Journal of Medicine 292 81-88. (doi:10.1056/NEJM197501092920207)

Schrier RW \& De Wardener HE 1971 $a$ Tubular reabsorption of sodium ion: influence of factors other than aldosterone and glomerular filtration rate. 1. New England Journal of Medicine 285 1231-1243. (doi:10.1056/ NEJM197111252852205)

Schrier RW \& De Wardener HE $1971 b$ Tubular reabsorption of sodium ion: influence of factors other than aldosterone and glomerular filtration rate. 2. New England Journal of Medicine 285 1292-1303. (doi:10.1056/ NEJM197112022852305)

Shaikh IM, Lau BW, Siegfried BA \& Valdes R Jr 1991 Isolation of digoxin-like immunoreactive factors from mammalian adrenal cortex. Journal of Biological Chemistry 266 13672-13678.

Shamraj OI \& Lingrel JB 1994 A putative fourth $\mathrm{Na}^{+}, \mathrm{K}^{+}$-ATPase $\alpha$-subunit gene is expressed in testis. PNAS 91 12952-12956. (doi:10.1073/pnas. 91.26.12952)

Shinoda T, Ogawa H, Cornelius F \& Toyoshima C 2009 Crystal structure of the sodium-potassium pump at 2.4 A resolution. Nature $\mathbf{4 5 9} 446-450$. (doi:10.1038/nature07939)

Siegfried BA \& Valdes R Jr 1988 Excretion of endogenous digoxin-like immunoreactive factors in human urine is a function of urine flow rate. Clinical Chemistry 34 960-964.

Skogen WF, Rea MR \& Valdes R Jr 1987 Endogenous digoxin-like immunoreactive factors eliminated from serum samples by hydrophobic silica-gel extraction and enzyme immunoassay. Clinical Chemistry 33 401-404.

Skou JC 1957 The influence of some cations on an adenosine triphosphatase from peripheral nerves. Biochimica et Biophysica Acta 23 394-401. (doi:10.1016/0006-3002(57)90343-8)

Skou JC \& Esmann M 1992 The Na,K-ATPase. Journal of Bioenergetics and Biomembranes 24 249-261. (doi:10.1007/BF00768846)

Slatopolsky E, Elkan IO, Weerts C \& Bricker NS 1968 Studies on the characteristics of the control system governing sodium excretion in uremic man. Journal of Clinical Investigation 47 521-530. (doi:10.1172/ JCI105748)

Slatopolsky E, Hoffsten P, Purkerson M \& Bricker NS 1970 On the influence of extracellular fluid volume expansion and of uremia on bicarbonate reabsorption in man. Journal of Clinical Investigation 49 988-998. (doi:10.1172/JCI106318)

Stella P, Manunta P, Mallamaci F, Melandri M, Spotti D, Tripepi G, Hamlyn JM, Malatino LS, Bianchi G \& Zoccali C 2008 Endogenous ouabain and cardiomyopathy in dialysis patients. Journal of Internal Medicine $\mathbf{2 6 3}$ 274-280. (doi:10.1111/j.1365-2796.2007.01883.x)

Sweadner KJ 1989 Isozymes of the $\mathrm{Na}^{+} / \mathrm{K}^{+}$-ATPase. Biochimica et Biophysica Acta 988 185-220. (doi:10.1016/0304-4157(89)90019-1) 
Sweadner KJ \& Rael E 2000 The FXYD gene family of small ion transport regulators or channels: cDNA sequence, protein signature sequence, and expression. Genomics 68 41-56. (doi:10.1006/geno.2000. 6274)

Sweadner KJ, Arystarkhova E, Donnet C \& Wetzel RK 2003 FXYD proteins as regulators of the Na,K-ATPase in the kidney. Annals of the New York Academy of Sciences 986 382-387. (doi:10.1111/j.1749-6632.2003. tb07218.x)

Tian J \& Xie ZJ 2008 The Na-K-ATPase and calcium-signaling microdomains. Physiology 23 205-211. (doi:10.1152/physiol.00008.2008)

Tian J, Cai T, Yuan Z, Wang H, Liu L, Haas M, Maksimova E, Huang XY \& Xie ZJ 2006 Binding of Src to $\mathrm{Na}^{+} / \mathrm{K}^{+}$-ATPase forms a functional signaling complex. Molecular Biology of the Cell 17 317-326. (doi:10.1091/mbc.E05-08-0735)

Tian J, Haller S, Periyasamy S, Brewster P, Zhang H, Adlakha S, Fedorova OV, Xie ZJ, Bagrov AY, Shapiro JI et al. 2010 Renal ischemia regulates marinobufagenin release in humans. Hypertension 56 914-919. (doi:10.1161/HYPERTENSIONAHA.110.155564)

Tokhtaeva E, Sachs G \& Vagin O 2009 Assembly with the Na,K-ATPase $\alpha_{1}$ subunit is required for export of $\beta_{1}$ and $\beta_{2}$ subunits from the endoplasmic reticulum. Biochemistry 48 11421-11431. (doi:10.1021/ bi901438z)

Tokhtaeva E, Sachs G, Souda P, Bassilian S, Whitelegge JP, Shoshani L \& Vagin O 2011 Epithelial junctions depend on intercellular transinteractions between the $\mathrm{Na}, \mathrm{K}-\mathrm{ATP}$ ase $\beta_{1}$ subunits. Journal of Biological Chemistry 286 25801-25812. (doi:10.1074/jbc.M111.252247)

Toustrup-Jensen MS, Holm R, Einholm AP, Schack VR, Morth JP, Nissen P, Andersen JP \& Vilsen B 2009 The C terminus of $\mathrm{Na}^{+}, \mathrm{K}^{+}$-ATPase controls $\mathrm{Na}^{+}$affinity on both sides of the membrane through $\mathrm{Arg}^{935}$. Journal of Biological Chemistry 284 18715-18725. (doi:10.1074/ jbc.M109.015099)

Valdes R Jr 1985a Endogenous digoxin-immunoactive factor in human subjects. Federation Proceedings 44 2800-2805.

Valdes R Jr 1985b Endogenous digoxin-immunoreactive substance measured in several patient populations. Progress in Clinical and Biological Research 192 221-228.

Valdes R Jr 1985c Endogenous digoxin-like immunoreactive factors: impact on digoxin measurements and potential physiological implications. Clinical Chemistry 31 1525-1532.

Valdes R Jr, Graves SW, Knight AB \& Craig HR 1985 Endogenous digoxin immunoactivity is elevated in hypertensive pregnancy. Progress in Clinical and Biological Research 192 229-232.

Valdes R Jr, Hagberg JM, Vaughan TE, Lau BW, Seals DR \& Ehsani AA 1988 Endogenous digoxin-like immunoreactivity in blood is increased during prolonged strenuous exercise. Life Sciences 42 103-110. (doi:10.1016/0024-3205(88)90629-7)

Wagoner K, Sanchez G, Nguyen AN, Enders GC \& Blanco G 2005 Different expression and activity of the $\alpha 1$ and $\alpha 4$ isoforms of the Na,K-ATPase during rat male germ cell ontogeny. Reproduction 130 627-641. (doi:10.1530/rep.1.00806) de Wardener H 2003 Presentation of the 2003 Jean Hamburger Award to Robert W. Schrier. Kidney International 64 1937-1938. (doi:10.1046/ j.1523-1755.2003.06453.x)

de Wardener HE \& MacGregor GA 2002 Harmful effects of dietary salt in addition to hypertension. Journal of Human Hypertension 16 213-223. (doi:10.1038/sj.jhh.1001374)

de Wardener HE, Mills IH, Clapham WF \& Hayter CJ 1961 Studies on the efferent mechanism of the sodium diuresis which follows the administration of intravenous saline in the dog. Clinical Science $\mathbf{2 1}$ 249-258.

de Wardener HE, He FJ \& MacGregor GA 2004 Plasma sodium and hypertension. Kidney International 66 2454-2466. (doi:10.1111/ j.1523-1755.2004.66018.x)

Weaver LC, Akera T \& Brody TM 1977 Digitalis toxicity: lack of marked effect on brain $\mathrm{Na}^{+}, \mathrm{K}^{+}$-adenosine triphosphatase in the cat. Journal of Phamacology and Experimental Therapeutics 200 638-646.

Woo AL, James PF \& Lingrel JB 1999 Characterization of the fourth $\alpha$ isoform of the Na,K-ATPase. Journal of Membrane Biology 169 39-44. (doi:10.1007/PL00005899)

Woo AL, James PF \& Lingrel JB 2000 Sperm motility is dependent on a unique isoform of the Na,K-ATPase. Journal of Biological Chemistry 275 20693-20699.

Wu J, Akkuratov EE, Bai Y, Gaskill CM, Askari A \& Liu L 2013 Cell signaling associated with $\mathrm{Na}^{+} / \mathrm{K}^{+}$-ATPase: activation of phosphatidylinositide 3-kinase IA/Akt by ouabain is independent of Src. Biochemistry $\mathbf{5 2}$ 9059-9067. (doi:10.1021/bi4011804)

Xie Z \& Askari A $2002 \mathrm{Na}^{+} / \mathrm{K}^{+}$-ATPase as a signal transducer. European Journal of Biochemistry 269 2434-2439. (doi:10.1046/ j.1432-1033.2002.02910.x)

Xie Z, Kometiani P, Liu J, Li J, Shapiro JI \& Askari A 1999 Intracellular reactive oxygen species mediate the linkage of $\mathrm{Na}^{+} / \mathrm{K}^{+}$-ATPase to hypertrophy and its marker genes in cardiac myocytes. Journal of Biological Chemistry 274 19323-19328.

Yoda A \& Yoda S 1981 The interaction of ouabagenin and $\left(\mathrm{Na}^{+}+\mathrm{K}^{+}\right)$ATPase in the presence of $\mathrm{Na}^{+}, \mathrm{Mg}^{2+}$, and ATP. Molecular Pharmacology 19 62-67.

Zhang YR \& Yuan ZY 2010 Dopamine-mediated inhibition of renal $\mathrm{Na}^{+} / \mathrm{K}^{+}$-ATPase in HK-2 cells is reduced by ouabain. Clinical and Experimental Pharmacology and Physiology 37 613-618. (doi:10.1111/ j.1440-1681.2010.05364.x)

Zhang Y, Yuan Z, Ge H \& Ren Y 2010 Effects of long-term ouabain treatment on blood pressure, sodium excretion, and renal dopamine $\mathrm{D}_{1}$ receptor levels in rats. Journal of Comparative Physiology B 180 117-124. (doi:10.1007/s00360-009-0391-z)

Zvartau NE, Conrady AO, Sviryaev YV, Rotari OP, Merkulova NK, Kalinkin AL, Shlyakhto EV \& Bagrov AY 2006 Marinobufagenin in hypertensive patients with obstructive sleep apnea. Cellular and Molecular Biology 52 24-27.

Received in final form 16 April 2014

Accepted 24 April 2014

Accepted Preprint published online 29 April 2014 http://joe.endocrinology-journals.org DOI: 10.1530/JOE-13-0613
C 2014 Society for Endocrinology Printed in Great Britain
Published by Bioscientifica Ltd. 